\title{
The xylem of anisohydric Quercus alba L. is more vulnerable to embolism than isohydric co-dominants
}

\author{
Michael Benson ${ }^{1}$, Chelcy Miniat ${ }^{2}$, Andrew Oishi ${ }^{3}$, Sander Denham ${ }^{1}$, Jean-Christophe \\ Domec $^{4}$, Daniel Johnson ${ }^{5}$, Justine Missik ${ }^{6}$, Richard Phillips ${ }^{7}$, Jeffrey Wood ${ }^{8}$, and Kimberly \\ Novick $^{7}$ \\ ${ }^{1}$ Indiana University System \\ ${ }^{2}$ USDA Forest Service, Southern Research Station, Coweeta Hydrologic Laboratory. \\ ${ }^{3}$ USDA Forest Service, Southern Research Station, Coweeta Hydrologic Laboratory \\ ${ }^{4}$ Bordeaux Sciences Agro \\ ${ }^{5}$ University of Georgia \\ ${ }^{6}$ Washington State University \\ ${ }^{7}$ Indiana University \\ ${ }^{8}$ University of Missouri
}

October 17, 2021

\begin{abstract}
The coordination of plant leaf water potential $\left(\Psi_{\mathrm{L}}\right)$ regulation and xylem vulnerability to embolism is fundamental for understanding the tradeoffs between carbon uptake and risk of hydraulic damage. There is a general consensus that trees with vulnerable xylem regulate $\Psi_{\mathrm{L}}$ more conservatively than plants with resistant xylem. We evaluated if this paradigm applied to three important eastern US temperate tree species, Quercus alba L., Acer saccharum Marsh., and Liriodendron tulipifera L., by synthesizing $1600 \Psi_{\mathrm{L}}$ observations, 122 xylem embolism curves, and xylem anatomical measurements across ten forests spanning pronounced hydroclimatological gradients and ages. We found that, unexpectedly, the species with the most vulnerable xylem ( $Q$. alba) regulated $\Psi_{\mathrm{L}}$ less strictly than the other species. This relationship was found across all sites, such that coordination among traits was largely unaffected by climate and stand age. Quercus species are perceived to be among the most drought tolerant temperate US forest species; however, our results suggest their relatively loose $\Psi_{\mathrm{L}}$ regulation in response to hydrologic stress occurs with a substantial hydraulic cost that may expose them to novel risks in a more drought-prone future. We end by discussing mechanisms that allow these species to tolerate and/or recover from hydraulic damage.
\end{abstract}

1. Title Page

The xylem of anisohydric Quercus alba L. is more vulnerable to embolism than isohydric co-dominants

Running Head: Hydraulic vulnerability in temperate US forests

Michael C. Benson ${ }^{1}$, Chelcy F. Miniat ${ }^{2}$, A. Christopher Oishi ${ }^{2}$, Sander O. Denham ${ }^{1}$, Jean-Christophe Domec $^{3,4}$, Daniel M. Johnson ${ }^{5}$, Justine E. Missik ${ }^{6}$, Richard P. Phillips ${ }^{7}$, Jeffrey D. Wood ${ }^{8}$, Kimberly A. Novick $^{1}$

${ }^{1}$ O'Neill School of Public and Environmental Affairs, Indiana University Bloomington. 1315 East Tenth Street, Bloomington, Indiana, 47405, USA 
${ }^{2}$ USDA Forest Service, Southern Research Station, Coweeta Hydrologic Laboratory. 3160 Coweeta Lab Rd, Otto, North Carolina 28763 USA

${ }^{3}$ Bordeaux Sciences Agro, INRA UMR 1391 ISPA, Gradignan F - 33170, France

${ }^{4}$ Nicholas School of the Environment, Duke University, Durham, North Carolina 27708

${ }^{5}$ Warnell School of Forestry and Natural Resources, University of Georgia, Athens, GA 30602, USA

${ }^{6}$ Laboratory for Atmospheric Research, Department of Civil and Environmental Engineering, Washington State University, Pullman, WA, USA

${ }^{7}$ Department of Biology, Indiana University - Bloomington. 1001 E 3rd St, Bloomington, Indiana 47405, USA

${ }^{8}$ School of Natural Resources, University of Missouri - Columbia. 1111 Rollins St., Columbia, Missouri, 65211, USA

Author for correspondence:

Michael C. Benson

Tel: $+1(405) 4437070$

Email: micbenso@iu.edu

\section{Keyword Index}

Acer saccharum Marsh., embolism vulnerability, isohydricity, leaf water potential, Liriodendron tulipifera L., temperate deciduous forests, Quercus alba L.

4. Introduction

When plants are water-limited, adaptive stomatal closure can alleviate stress on the plant hydraulic system by reducing water loss to the atmosphere and preventing the development of excessively low plant water potentials (Buckley, 2005). However, because stomatal closure also down-regulates leaf carbon fluxes, there can be deleterious consequences for plant health from reduced photosynthesis. Regulation of plant water status differs widely across tree species and is often characterized along a continuum of quantitative metrics describing leaf water potential $\left(\Psi_{\mathrm{L}}\right)$ regulation in response to hydrologic stress (Tardieu \& Simonneau, 1998; McDowell et al ., 2008; Klein, 2014; Meinzer et al ., 2016; Matheny et al.,2017; Hochberg et al., 2018). Across this continuum, species may exhibit relative loose regulation of stomatal conductance in response to declining soil water and/or rising evaporative demand, allowing $\Psi_{\mathrm{L}}$ to decline as hydrologic stress evolves (i.e., more 'anisohydric' behavior, Martínez-Vilalta et al ., 2014). By comparison, other species may exhibit stricter regulation of plant water loss by closing their stomata to minimize $\Psi_{\mathrm{L}}$ decline (i.e., more 'isohydric' behavior). A less negative $\Psi_{\mathrm{L}}$ maintains the turgor pressure necessary for leaf cell growth and expansion and is an important factor determining the risk of damage to the hydraulic system from xylem embolism (Tyree \& Zimmerman, 2013).

Embolisms propagate throughout xylem elements when hydrologic stress causes excessively large tension forces (e.g., very low water potential) in the plant hydraulic system (Tyree \& Sperry, 1989; Davis et al ., 1999). As a result, water transport to active sites of photosynthesis becomes restricted. The coordination of $\Psi_{\mathrm{L}}$ regulation and vulnerability of xylem tissues is therefore fundamental for understanding the tradeoffs between carbon uptake and risk of hydraulic damage across vegetative species. The prevailing view is that trees with more vulnerable xylem tend to be more isohydric (Bond \& Kavanagh, 1999; Schultz, 2003; McDowell et al ., 2008; Taneda \& Sperry, 2008; Choat et al ., 2012; Plautet al ., 2012; Meinzer et al ., 2014; Skelton et al.,2015; Sperry \& Love, 2015; Garcia-Forner et al ., 2016), as they operate with smaller safety margins to xylem embolism and therefore require careful regulation of $\Psi_{\mathrm{L}}$ to avoid hydraulic damage. 
This view on the coordination of stomatal regulation of $\Psi_{\mathrm{L}}$ and xylem vulnerability is implicit in the recent incorporation of new plant hydraulic schemes into terrestrial ecosystem models (TEM) (Naudts et al. , 2015; Kennedy et al., 2019; Mirfenderesgi et al ., 2019). The TEM frameworks differ in the way that hydraulics and leaf-level gas exchange processes are mathematically linked; however, all fundamentally relate the stomatal sensitivity to declining plant or soil water potential $\left(\Psi_{S}\right)$ to the shape of the xylem vulnerability curve. The ability of a model to link xylem vulnerability to isohydric behavior is even viewed as an important check on a model's functionality (Sperry \& Love, 2015).

Much of what we know about coordination between $\Psi_{\mathrm{L}}$ and xylem vulnerability to embolism has relied on a legacy of observations from dryland ecosystems (McDowell et al ., 2008; Taneda \& Sperry, 2008; Plaut et al ., 2012; Skelton et al ., 2015), where plants are generally adapted to arid environments, but excessive drought conditions have promoted widespread mortality (Macalady \& Bugmann, 2014; Meddens et al ., 2015). Less is known about the coordination of these hydraulic traits in temperate eastern US deciduous forests, where drought stress is relatively less severe but may become more frequent in the future (Dai, 2011; Novick et al ., 2016). Eastern deciduous forests have tall canopies and dense foliage in which plants must compete for space (Olivier et al ., 2016). While drought-induced mortality periodically occurs in these ecosystems (Elliott \& Swank, 1994; Dietze \& Moorcroft, 2011; Wood et al ., 2018), trees must balance conserving hydraulic function with maintaining sufficient productivity and growth to compete for light. Given these constraints, it is not clear that water-use strategies which adhere to strict coordination between stomatal behavior and xylem vulnerability should necessarily confer a universal advantage across diverse ecosystems.

A tenuous understanding of intraspecific patterns of vulnerability (Anderegg, 2015) further challenges our understanding of tradeoffs between xylem vulnerability and $\Psi_{\mathrm{L}}$ regulation. Species which encompass broad climate envelopes sometimes acclimate their xylem tissues to thrive across diverse environmental conditions (Maherali \& Delucia, 2000; Herbette et al ., 2010; Wortemann et al ., 2011). Coordination of hydraulic traits may also change over time, reflecting long-term, plastic responses to drought such as changes in xylem anatomy (e.g., vessel diameter) that produce more resistant xylem (Maherali et al ., 2006). Understanding intraspecific embolism vulnerability in both space and time is particularly important for eastern US deciduous forests, which are highly productive, species-rich, environmentally diverse, and characterized by uneven-aged stands from a legacy of management and disturbance (Pan et al ., 2011).

Our objective is to identify inter- and intraspecific patterns of hydraulic traits in important eastern US deciduous forest species, focusing on those traits which determine stomatal regulation of $\Psi_{\mathrm{L}}$ in response to rising vapor pressure deficit $(D)$ and declining soil moisture (Tardieu \& Simonneau 1998; Domec \& Johnson, 2012; Novick et al ., 2019). Our study species areQuercus alba L., Acer saccharum Marsh., Liriodendron tulipifera L.- which are among the region's most dominant. Q. alba, A. saccharum, and L. tulipifera are the $5^{\text {th }}, 6^{\text {th }}$, and $17^{\text {th }}$ most abundant species (out of 134) in eastern US forests (Iversonet al., 2008). These species differ widely in terms of xylem anatomy ( $Q$. alba are ring-porous whereas A. saccharum and $L$. tulipifera and are diffuse-porous) and in terms of stomatal regulation strategy ( $Q$. alba are more anisohydric than the other species, Meinzer et al ., 2013; Roman et al., 2015, Mathenyet al ., 2017, Denham et al. 2021). We seek to understand: 1) to what extent is regulation of $\Psi_{\mathrm{L}}$ coordinated with embolism resistant tissues across these three species? and 2) how does this relationship vary as a function of the diverse hydroclimatological conditions and regenerative states that these species occupy? To that end, we test the following three hypotheses:

1) Trees invest in more resistant xylem when growing in regions that more regularly experience moisture stress.

2) Stem tissues are more vulnerable to embolism in shorter, younger stands than in taller, more mature stands, because taller trees will have developed more resistant xylem to overcome additional constraints on water movement from increased canopy height (McDowell et al ., 2002; Novick et al ., 2009).

3) Stem tissues of more anisohydric trees will be more resistant to hydraulic dysfunction than trees that more rapidly close their stomata to limit $\Psi_{\mathrm{L}}$ decline (e.g., isohydric behavior). This hypothesis reflects the 
prevailing view that the vulnerability of xylem tissues to embolism is linked to more isohydric behavior.

To test these hypotheses, we analyzed stem xylem anatomy, stem embolism vulnerability, and $\Psi_{\mathrm{L}}$ observations across ten forest stands of differing age and climates that broadly represented the climate envelopes of the study species' native range. By testing these hypotheses, we will better understand the extent to which coordination of hydraulic traits in primarily energy-limited forests aligns with paradigms emerging from more water-limited biomes. Our results may also inform our understanding of an ongoing and persistent decline in eastern US Quercus species across much of their native range (Feiet al ., 2011). Quercus species rank high in species diversity, biomass, and carbon storage (Cavender-Bares, 2016), and account for $\sim 25 \%$ of all growing timber stock in the eastern US (Fei et al ., 2011). While the causes of decline are a matter of debate (McEwan et al., 2011), most of them are rooted in assumptions about how Quercus versus nonQuercusspecies function during periods of hydrologic stress. Whether Quercus species - which are putatively drought-tolerant species (Abrams, 1990; Cavender-Bares, 2019) - will thrive or falter under future conditions characterized by more frequent and severe drought stress is an important unresolved question.

5. Materials and Methods

\subsection{Study sites}

We selected ten forest stands across four regions in the eastern US that spanned a hydroclimatological gradient (Fig. 1, Table 1). Four of the stands were $~ 85$-year-old temperate deciduous forest AmeriFlux sites (US-MMS, US-CWT, US-Dk2, and US-MOz) in the states of Indiana (IN), North Carolina (NC), and Missouri (MO). The gradient approach allowed us to understand how key plant hydraulic traits varied as a function of climate. Additionally, the $~ 85$-year-old stands in IN and NC were each end-members of a chronosequence (including $\sim 15$ - and $\sim 35$-year-old stands co-located within $20 \mathrm{~km}$ of the $\sim 85$-year-old stand). The chronosequences in NC and IN allowed us to investigate how the relationship between $\Psi_{\mathrm{L}}$ behavior and vulnerability to hydraulic failure varied with stand age in regions experiencing a similar climate.

Indiana chronosequence stands:

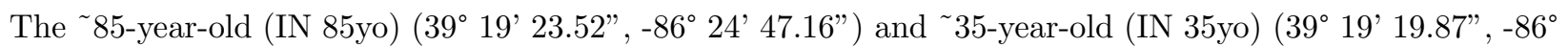
$28^{\prime}$ 51.92") IN stands were located in Morgan-Monroe State Forest. Dominant species were A. saccharum, L. tulipifera, Q. alba, Sassafras albidum Nutt., Quercus rubra L., and denseLindera benzoin L. understory (Roman et al ., 2015). Deep silt clay loam soils characterized the sites $(90-120 \mathrm{~cm})$. The 15 -year-old stand (IN 15yo) (39 $\left.13^{\prime} 10.93^{\prime \prime},-86^{\circ} 32^{\prime} 30.96^{\prime \prime}\right)$ was a nearby (<20 km) regenerating planting with similar species composition located at The Indiana Research and Teaching Preserve's Bayles Road site. There, 5-year-old saplings of common Indiana forest tree species from local forest seed stock were planted in 2006 at a spacing of $5.25 \mathrm{~m} \times 5.25 \mathrm{~m}$ and in random $12 \times 12$ arrangements (Flory \& Clay, 2010).

Western North Carolina chronosequence stands:

The 85-year-old (NC_W 85yo) (353' 33.12", -83²5' 39") and 35-year-old (NC_W 35yo) (35³' 55.22", $\left.-83^{\circ} 26^{\prime} 17.54^{\prime \prime}\right)$ stands in the western NC chronosequence were located in the Coweeta Basin, at the USDA Forest Service Coweeta Hydrologic Laboratory. Soils were fine-loamy with a variable depth of approximately 35 to $>90 \mathrm{~cm}$. The NC_W 85yo was a mature, secondary forest dominated by L. tulipifera, Q. alba, Acer rubrum L., Betula lenta L., and dense Rhododendron maximum L. understory (Oishiet al. , 2018). The NC_W 35yo stand had similar species composition, but was clearcut in 1976-1977 (Swank \& Webster, 2014). The 15-year-old NC stand (NC 15yo) (35deg 10'47.71", -83deg 29'44.98") was a selectively harvested stand located nearby $(<20 \mathrm{~km})$ in the Nantahala National Forest with similar species composition.

Eastern North Carolina chronosequence stands:

The 85-year-old (NC_E 85yo), 35 -year-old (NC_E 35yo), and 15-year old (NC_E 15yo) eastern NC chronosequence stands were located in the Blackwood Division of Duke Forest (35deg 58' 24.89", -79deg 6' 1.55"). NC_E 85yo was a naturally established stand comprised of mixed hardwood species $Q$. alba , Quercus michauxii Nutt., L. tulipifera, Liquidambar styraciflua L, and hickory species Carya tomentosa 
Sarg. and Carya glabra Miller (Oishiet al., 2010). NC_E 35yo was located less than 4 km from NC_E 85yo and was part of the former Duke FACE project ambient plots. This site was clear-cut in 1982 to remove a 50-year-old mixed pine forest and was replanted in 1983. The stand was dominated by Pinus taeda L. but Q. alba , L. tulipifera, A. rubrum, L. styraciflua, Cornus florida L. and Prunus serotina Ehrh. occurred in the understory and stand gaps. Soils were gravelly loam of the Iredell series with majority of the rooting zone occurring at 45-65 cm depth (Domec et al., 2012).

A. saccharum trees were sampled in the NC_E chronosequence from an additional lowland hardwood stand located $15 \mathrm{~km}$ from the ones described above. Fagus grandifolia Ehrh. was the dominant canopy tree species of this lowland hardwood site, but Q. alba, Q. rubra, L. styraciflua, and A. saccharum occurred frequently in the understory. This site was also part of the Duke Forest but was characterized by a deep and well-drained soil with minimal disturbance.

\section{Missouri stand:}

The 85 -year-old MO stand (MO 85yo) (38deg 44' 38.76", -92deg 12' 0") was located in the University of Missouri's Baskett Wildlife Research and Education Area. It is a comparitively xeric secondary oak-hickory forest, with dominant species of Q. alba, Quercus velutina Lam., A. saccharum, Carya ovata (Mill.) K. Koch, and Juniperus virginiana L. (Wood et al ., 2018). While this site received similar annual precipitation to IN and NC_E, high precipitation variability and comparatively shallow silt loam soils imposed frequent and severe physiological drought (Gu et al. , 2015; Gu et al. , 2016).

\subsection{Study Species}

While our study species (Q. alba, A. saccharum, L. tulipifera ) occupy wide ranges, unfortunately not every species was present in each study site. Nevertheless, we were able to sample at least two species in each location (Table 1).

\subsection{Characterizing midday $\Psi_{\mathrm{L}}$ regulation}

Periodic midday $\Psi_{\mathrm{L}}$ measurements (10:00-16:00 local time) were compiled from a dataset of over 1600 observations collected throughout the growing seasons of 2011-2017. On each measurement day, one to five samples were collected from one to three trees per species from the upper third of the canopy. Leaves were bagged for $\sim 15$ minutes prior to excision to allow $\Psi$ of the leaf cells and stem xylem to reach equilibrium (Leach et al. , 1982; Roman et al. , 2015); this approach was conducted in every site except for IN 35yo where canopies were inaccessible from the ground or by cherry picker. After excision, $\Psi_{\mathrm{L}}$ was measured using a pressure chamber (PMS Instruments, Corvallis, OR, USA) (Turner, 1988) immediately in the field, or after leaves were transferred to the lab in humidified bags stored in a cooler. All together, we made 704, 178, and $757 \Psi_{\mathrm{L}}$ observations of L. tulipifera, A. saccharum, and Q. alba, respectively. The number of $\Psi_{\mathrm{L}}$ observations and sampling days varied across regions, but $\Psi_{\mathrm{L}}$ was measured on 4-51 different days at each stand, including sampling at the beginning (June) and end (September) of the growing season to permit observation throughout dynamic seasonal changes of moisture conditions.

While regulation of plant water status is frequently characterized as the sensitivity of $\Psi_{\mathrm{L}}$ to declining $\Psi_{\mathrm{S}}($ McDowell et al ., 2008; Klein, 2014; Martínez-Vilalta et al ., 2014; Matheny et al., 2015; Meinzer et al.,2017), this metric of isohydricity can change temporally as drought evolves (Hochberg et al., 2018; Wu et al.,2021), and is often inconsistent for the same species from one stand to the next (Martínez-Vilalta \& Garcia-Forner, 2017). These inconsistencies likely reflect the fact that the degree of isohydricity, when defined as $\partial \Psi_{L} / \partial \Psi_{S}$, is complicated by environmental interactions (Hochberg et al ., 2018), including variability in $D$ which can also affect $\Psi_{\mathrm{L}}$ (Domec \& Johnson, 2012; Novick et al ., 2019), or when the magnitude of soil water deficit during the sampling period is insufficient to capture stress responses (Martínez-Vilatla \& Garcia-Forner, 2017). Another proposed metric - the "hydroscape" concept (Meinzer et al., 2016; Li et al., 2019) based on the integrated area between the observed $\Psi_{L}-\Psi_{S}$ curve - can overcome some of the conceptual difficulties associated with $\partial \Psi_{L} / \partial \Psi_{S}$. However, the hydroscape is still fundmentally informed by the relationship between $\Psi_{L}$ and $\Psi_{S}$. Thus, the hydroscape does not directly account for variability in $\Psi_{\mathrm{L}}$ 
driven by $D$ and can be hard to quantify in mesic sites where $\Psi_{S}$ may be relatively stationary even while temperature-driven variation in $D$ may be large.

Negative excursions in $\Psi_{L}$ driven by $D$ may be especially important in eastern US forests, where limitations to stomatal conductance from $D$ have been shown to dominate over soil water limitations, at both the stand (Novick et al ., 2016) and tree-scale (Yi et al., 2019; Denham et al ., 2021). While substantial soil water deficits occurred in some of our sites (e.g., MO, NC_E, IN), the more mesic NC_W stands rarely experience soil water limitations, and soil water deficits were not observed during the study period (Fig. S1); however, $\Psi_{\mathrm{L}}$ reductions during periods of elevated $D$ occurred routinely (Fig. S2). For these reasons, we quantified isohydricity as the variability in seasonal midday $\Psi_{\mathrm{L}}$ to capture $\Psi_{\mathrm{L}}$ sensitivity to both declining soil moisture and increasing $D$ (See SI.1 for further discussion). To minimize error associated with uncharacteristic behavior during spring leaf out and fall senescence, $\Psi_{\mathrm{L}}$ data used for this analysis were constrained to a period of relatively stationary leaf area index (days of year 150-270).

\subsection{Xylem embolism vulnerability curves}

Vulnerability to hydraulic failure was estimated with cavitation-induced embolism curves. The relationship between the loss of hydraulic function and stem xylem water potential $\left(\Psi_{\mathrm{x}}\right)(\mathrm{MPa})$ was measured on stem tissues $(n=3-5)$ from 2-3 trees per species at each stand, resulting in 6-12 curves per species per stand, or 165 total curves. Vulnerability curves were generated using the air-injection technique (Sperry \& Saliendra, 1994; Johnson et al ., 2016). Branches were harvested from the upper third of the canopy, and stem samples $20 \mathrm{~cm}$ in length were collected from the terminal bud of felled branches. Samples were stored at $5{ }^{\circ} \mathrm{C}$ submerged in deionized water that was replenished daily and were measured within two weeks of collection.

We used a pressure flow meter (XYL'EM embolism meter, Bronkhorst, Montigny les Cormeilles, France) to measure stem hydraulic conductivity $\left(K_{\text {stem }}\right)\left(\mathrm{kg} \mathrm{m}^{-1} \mathrm{~s}^{-1} \mathrm{MPa}^{-1}\right)$, and a pressure sleeve (Scholander Pressure Chamber model 1505D, PMS Instruments, Corvallis, OR, USA) to facilitate air-injection. Samples were rehydrated by flushing native embolism in submerged deionized water under vacuum for $24+$ hours. Following rehydration, stem samples were exposed to positive air pressure in 0.5 to $1.0 \mathrm{MPa}$ increments until $>85 \%$ reduction of maximum $K_{\text {stem }}$ was reached or the applied pressure approached instrument limitation. We then corrected $K_{\text {stem }}$ to $20{ }^{\circ} \mathrm{C}$ to account for changing viscosity of water with temperature $\left(K_{20}\right)\left(\mathrm{kg} \mathrm{m}^{-1}\right.$ $\left.\mathrm{s}^{-1} \mathrm{MPa}^{-1}\right)$. The percent loss of conductivity (PLC) (\%) at a given applied pressure was calculated as:

$P L C=100 \times\left(1-\frac{K_{20}}{K_{\max }}\right)(1)$

where $K_{\max }$ is temperature corrected $\operatorname{maximum} K_{\text {stem }}$ when applied pressure $=0 \mathrm{MPa}$.

The relationship between PLC and $\Psi_{\mathrm{x}}$ was then fitted to the sigmoid function provided by Maherali et al ., (2006):

$P L C=\frac{100}{\left[1+\exp \left(\alpha\left(\Psi_{x}-b\right)\right)\right]}(2)$

where $a$ and $b$ are empirical coefficients determined using nonlinear curve fitting (MATLAB, The Mathworks Inc., Natick, MA, USA; v. R2018a). The fitted relationship was then used to calculate the $\Psi_{\mathrm{x}}$ at which $12 \% \mathrm{PLC}(\mathrm{P} 12, \mathrm{MPa})$ and $50 \% \mathrm{PLC}(\mathrm{P} 50, \mathrm{MPa})$ occurred. The P50 was set equal to the $b$ parameter, and P12 calculated as $2 / a+b$, as described by Domec \& Gartner (2001). The value P12, termed the air entry point, is an estimate of the xylem tension at which the resistance to air entry of pit membranes within the conducting xylem is overcome and cavitation and embolism begin.

The measurement and interpretation of the vulnerability curves was guided by extensive quality control to minimize sources of bias. Specifically, while the air-injection method remains the most popular technique for assessing vulnerability to embolism (Sperry \& Saliendra, 1994; Johnson et al ., 2016), measurement artifacts from destructive sampling, such as the presence of open vessels, may over-estimate in-situ vulnerability (Martin-StPaul et al ., 2014). This bias may be particularly important for long-vesseled species like Q. alba (Cochard \& Tyree, 1990). We therefore took multiple steps to minimize the presence of open vessels and to remove any curves that appeared to be affected by open vessel artifacts: 
[1] First, we sampled young distal tissues from branch apices, which have relatively short vessels (Cochard \& Tyree, 1990). WhileQuercus species can have vessels that extend to several meters in length, long vessels are less prevalent in young stems and distal branches (Cochard \& Tyree, 1990; Fontes \& Cavender-Bares, 2020). Thus, we collected only these tissue sections to increase the likelihood that xylem elements were short in length.

[2] Second, while many studies avoid open vessel artifacts by collecting branch samples that are twice the length of a reference average vessel length, we did not assume that our samples contained intact vessels. Instead, we directly tested for the presence of open vessels using an air-infiltration technique (Cochard et $a l ., 2010)$. We discarded every stem that allowed low pressure air to freely pass through, indicating severed vessel end walls were present (Cochardet al., 2010). This was a labor-intensive step that required collecting a substantially greater number of stems than were ultimately used for vulnerability curves; however, it was necessary to ensure that $Q$. alba samples had intact vessels.

[3] Third, we carefully considered the shape of the vulnerability curves and removed any that contained signatures of open vessel artifacts, noting that curves that are conspicuously ' $r$ ' shaped are likely affected by open vessel artifacts, and that 's' shaped curves more accurately represent in-situ vulnerability (Torres-Ruizet al ., 2014; Skelton et al., 2018). We defined an 's' shape curve as one that lost less than $7.5 \%$ of its $K_{\max }$ as $\Psi_{\mathrm{x}}$ declined from 0 to $-0.5 \mathrm{MPa}$ and screened our dataset to use only these curves. We performed the analysis at alternative cutoff thresholds of $3 \%, 5 \%$, and $10 \%$ loss of $K_{\max }$, but there were no noticeable effect on the results. Overall, including both ' $\mathrm{s}$ ' and ' $\mathrm{r}$ ' curves had little impact on characterizing embolism thresholds (Fig. S3). Nevertheless, 'r-shaped' curves for any species were not included for subsequent analyses, resulting in 40, 56, 26 suitable 's-shaped' curves for L. tulipifera, Q. alba, and A. saccharum, respectively (or $74 \%$ of the original 165 curves, Table S1).

\subsection{Xylem anatomy}

To understand how changes in xylem vulnerability are linked to variations in xylem anatomy, we measured vessel lumen area and vessel density on transverse sections ( $\sim 40 \mu \mathrm{m}$ width) extracted from stems used for embolism vulnerability measurements. Unfortunately, stem samples were unavailable from $\mathrm{MO}$ and for $A$. saccharum in the IN 85yo stand (Table S1).

Stem samples were softened by boiling in deionized water and sectioned by hand using a fresh razor blade (Schweingruber, 2007). Prior to analysis under the microscope, samples were oven-dried at $150{ }^{\circ} \mathrm{C}$ to reduce light refraction from water remaining in lumen areas. Slides from the NC_W and IN were imaged with a stereoscope and color camera at 150×magnification (Leica M205F, Leica DFC310FX, Leica Microsystems, Heerbrugge, Switzerland). Vessel lumen area and density were then calculated using threshold balance manipulation and the analyze particle function of ImageJ v1.6 software (National Institutes of Health, USA) (Scholz et al ., 2013). Slides from the NC_E were photographed at 100× and 200× magnifications and analyzed using the Motic Images Advanced 3.2 software (Motic Corporation, Zhejiang, China).

\subsection{Data processing and analysis}

We investigated differences in P12 and P50 across species and stands (hypotheses 1 and 2) with a two-way ANOVA, where species and stand age were fixed factors and region was a blocking factor. We compared vessel density and lumen area with a two-way ANOVA, where species and stand age were fixed factors. We removed region as a blocking factor because there was no significant region or region interaction effect at $p$ $=0.05$. The relationships between xylem anatomy (e.g., vessel density and vessel lumen area) and embolism thresholds (e.g., P12 and P50) were assessed with a least squares linear regression within and across species. All ANOVA analyses were performed at the $\alpha=0.05$ level and were followed by a Tukey post-hoc test for significant main effects. Significant interaction terms were assessed by pairwise comparison of least square means.

We analyzed the relationship between embolism thresholds and degree of isohydricity (hypothesis 3) in two ways. First, we used $i n$-situ $\Psi_{\mathrm{L}}$ observations and laboratory generated xylem embolism curves to estimate 
the percent of native embolism across species and stands during the study period. Specifically, we used the minimum $\Psi_{\mathrm{L}}$ observation $\left(\Psi_{\mathrm{L}, \mathrm{min}}\right)$ of a non-transpiring (bagged) leaf for each species in each stand as an approximation of equilibrated $\Psi_{\mathrm{x}}$ (Williams \& Araujo, 2002; Zhang et al., 2013). While this approach is common (Choatet al., 2010; Zhang et al., 2013; Johnson et al.,2016), a gradient often exists between stem xylem and distal tissues such that $\Psi_{\mathrm{L}}$ and $\Psi_{\mathrm{x}}$ are not always equal (Simonin et al., 2015; Johnson et al., 2016; Holtzmanet al ., 2021). However, $\Psi_{\mathrm{L}}$ and $\Psi_{\mathrm{x}}$ are often correlated and most similar when hydrologic stress forces stomatal closure (Holtzman et al., 2021). Thus, $\Psi_{\mathrm{L}, \min }$ as determined from bagged leaves is likely a close approximation of $\Psi_{\mathrm{x}}$. but may over-estimate true extent of embolism propagation if equilibration between $\Psi_{\mathrm{L}}$ and $\Psi_{\mathrm{x}}$ was not achieved during bagging. Nevertheless, estimating native embolism in this manner yielded similar values to those reported in the literature for L. tulipifera (Johnson et al., 2016), A. saccharum (Wheeleret al., 2013), and Quercus species (Sperry \& Sullivan 1992; Taneda \& Sperry, 2008; Peguero-Pina et al., 2018). We assessed differences in estimated native embolisms across species and stands with a two-way ANOVA, where species and stand age were fixed factors and region was a blocking factor. The relationship between native embolism and degree of isohydricity was then assessed with a least square linear regression between mean estimated native embolism and interquartile range of $\Psi_{\mathrm{L}}$ of each species in each stand. We excluded IN 35yo data from this analysis because leaf bagging was not possible in this site (see section 5.3).

Second, we investigated hypothesis 3 in the context of a hydraulic safety margin $\left(\Psi_{\text {safety }}\right)$ (MPa). Safety margins from P12 $\left(\Psi_{\text {safety, P12 }}\right)(\mathrm{MPa})$ and P50 ( $\left.\Psi_{\text {safety, P50 }}\right)(\mathrm{MPa})$ were calculated as (Domec \& Gartner, 2001; Delzon \& Cochard, 2014):

$\Psi_{\text {safety }}=\Psi_{L, \min }-\Psi_{\text {thresh }}(3)$

where $\Psi_{\text {thresh, }}(\mathrm{MPa})$ is mean embolism threshold (e.g., P12 or P50) for the same species in the same stand. A negative $\Psi_{\text {safety }}$ suggests a high level of xylem embolism, while a positive $\Psi_{\text {safety }}$ suggests a window of safety from critical levels of xylem damage (Johnson et al ., 2016). We then performed a least square linear regression between $\Psi_{\text {safety }}$ and the $\Psi_{\mathrm{L}}$ interquartile range across species and stands. $\Psi_{\text {safety }}$ should characterize the difference between the largest xylem water tensions experienced by the plant and the level of water stress leading to a threshold of hydraulic failure (Domec \& Gartner, 2001; Delzon \& Cochard, 2014). Therefore, we considered whether these analyses were sensitive to hydrologic conditions during the study period, since the observed $\Psi_{\mathrm{L}}$ min may underestimate $\Psi_{\mathrm{L}}$ during extreme exposure to drought (Bhaskar \& Ackerly, 2006). We used parametric bootstrapping to quantify a range of slopes of the relationship between $\Psi_{\mathrm{L}}$ interquartile range and $\Psi_{\text {safety }}$ and $\Psi_{\mathrm{L}}$ interquartile range and estimated native embolism. Specifically, for each unique site-species combination, we created normal distributions of each variable using the observed mean and standard deviation of each metric for each site-species. We then drew 100 estimates of $\Psi_{\mathrm{L}}$ from the lowest $10 \%$ quantile of 50,000 data points drawn from the normal $\Psi_{\mathrm{L}}$ distribution, and 100 estimates of $\Psi_{\text {thresh }}$ from the middle $60 \%$ of 50,000 data points drawn from the normal $\Psi_{\text {thresh }}$ distribution. We experimented with a range of thresholds for the $\Psi_{\mathrm{L}}$ quantile, ultimately selecting $10 \%$ as it produced estimates of $\Psi_{\mathrm{L}}$ that were at least occasionally lower than the observed minimum $\Psi_{\mathrm{L}}$ for each site-species. However, most of the simulated $\Psi_{\mathrm{L}}$ within this quantile were greater than the observed minimum $\Psi_{\mathrm{L}}$, such that this is a relatively conservative approach that underestimates the minimum $\Psi_{\mathrm{L}}$ more than it overestimates it. In future work, other probability distributions, including extreme value distributions (Martínez-Vilatla et al., 2021) could be used instead. Together, these simulated data gave us 100 estimates of $\Psi_{\text {safety }}$ that accommodated uncertainty in both $\Psi_{\mathrm{L}}$ and $\Psi_{\text {thresh }}$ and allowed us to estimate 100 unique slopes of the relationship between $\Psi_{\text {safety }}$ and the $\Psi_{\mathrm{L}}$ interquartile range. Again, we excluded data from the IN 35yo site in this analysis.

\section{Results}

\subsection{Spatio-temporal variation in embolism vulnerability}

We found little variation in embolism vulnerability across stands, though embolism thresholds were markedly different across species $\left(F_{n d f, d d f}=149.87, p=0.001\right.$ for P12, and $F_{n d f, d d f}=169.62, p=0.003$ for P50, Fig. 2 ). At the P50 threshold, we detected some variability arising from the interaction between species and age 
$\left(F_{n d f, d d f}=18.88, p=0.017\right.$, Table 2$)$ and age and region $\left(F_{n d f, d d f}=21.312, p=0.016\right.$, Table 2$)$. Specifically, we found that $A$. saccharum P50 differed between young (15yo) and intermediate (35yo) stands, although embolism vulnerabilities were invariant across stand ages for $Q$. alba and L. tulipifera (Fig. 3a). Additionally, across all species, young stands (15yo) had more vulnerable xylem in the mesic NC_W stands than in the drier IN and NC_E stands; however, this pattern was not observed for the 35yo and 85yo age classes (Fig. 3 b). In general, $Q$. albahad the most vulnerable xylem while A. saccharum had the least (Fig. 2). Mean $\mathrm{P} 12$ across all stands were $-1.09 \mathrm{MPa}(\mathrm{SE}=0.06),-1.65 \mathrm{MPa}(\mathrm{SE}=0.10)$, and $-2.75 \mathrm{MPa}(\mathrm{SE}=0.20)$ and mean $\mathrm{P} 50$ was $-2.72 \mathrm{MPa}(\mathrm{SE}=0.09),-3.91 \mathrm{MPa}(\mathrm{SE}=0.12)$, and $-4.77 \mathrm{MPa}(\mathrm{SE}=0.18)$ for $Q$. alba, $L$. tulipifera, and A. saccharum, respectively.

6.2 Relationship between xylem anatomy and embolism vulnerability

Xylem anatomy varied considerably between ring-porous $Q$. alba and diffuse-porous species L. tulipifera and A. saccharum. A. saccharum and L. tulipifera mean lumen areas were indistinguishable, but significantly smaller than $Q$. alba $\left(F_{n d f, d d f}=124.37, p=<0.001\right.$, Table 3, Fig. 4). By comparison, mean vessel densities were different across all species (Fig. 5c); however $Q$. alba stems had consistently lower vessel density than $L$. tulipifera and A. saccharum $\left(F_{n d f, d d f}=208.982, p=<0.001\right.$, Table 3, Fig. 5). Additionally, we detected no influence of local climate or age on mean lumen area or vessel density, such that xylem traits were generally conserved at the species-level (region, age, or interactions not significant).

Xylem anatomy had moderate explanatory power for tissue level embolism vulnerability. Across species, stems with larger vessel lumen area (Fig. 4d) and smaller vessel densities (Fig. 5d) approached 50\% loss of hydraulic function at less negative $\Psi_{\mathrm{x}}\left(R^{2}=0.431, p=<0.001\right.$ for lumen area, and $R^{2}=0.450, p=$ $<0.001$ for vessel density). Patterns with P12 were similar, but generally weaker than in relation to P50. Specifically, tissues with larger mean vessel lumen area tended to approach $12 \%$ loss of hydraulic function at lower $\Psi_{\mathrm{x}}$ relative to tissues with smaller mean lumen area $\left(R^{2}=0.250, p=0.005\right.$, Fig. $\left.4 \mathrm{~b}\right)$. Tissues with greater vessel densities were generally more embolism-resistant at $\mathrm{P} 12\left(R^{2}=0.322, p=<0.001\right.$, Fig. $4 \mathrm{~b})$. However, this pattern was contradicted by $Q$. alba, where stems with greater vessel densities were more vulnerable to $12 \%$ loss of hydraulic function $\left(R^{2}=0.26, p=0.002\right.$, Fig. $\left.5 \mathrm{~b}\right)$.

6.3 Diagnosing leaf water status and leaf hydraulic strategy

Seasonal midday $\Psi_{\mathrm{L}}$ values varied across species and stands, but in general, $Q$. alba experienced a lower overall midday $\Psi_{\mathrm{L}}$ and a broader range. Larger species-specific declines in midday $\Psi_{\mathrm{L}}$ occurred in the more arid forest stands (e.g., NC_E chronosequence and MO, Table 1), while the smallest occurred in NC_W 15yo (Fig. 6a). Leaf hydraulic strategy was primarily associated with species $\left(F_{n d f, d d f}=22.20, p=<0.001\right)$, and no influence of age on mean $\Psi_{\mathrm{L}}$ interquartile ranges were detected (age and age-species interactions not significant). The L. tulipifera and $A$. saccharum mean $\Psi_{\mathrm{L}}$ interquartile ranges were indistinguishable, but significantly lower than $Q$. alba (Fig. 6b). Overall, Q. alba displayed more anisohydric behavior while $L$. tulipifera and A. saccharum were more isohydric.

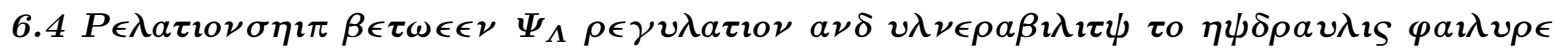

The most anisohydric species in our study possessed xylem that were more vulnerable to embolism than the more isohydric species. This pattern was consistent at both $\mathrm{P} 12$ and $\mathrm{P} 50$, where Q. alba (mean $\Psi_{\mathrm{L}}$ interquartile range $0.71 \pm 0.04 \mathrm{MPa}$ ) embolism thresholds were consistently greater than the more isohydric L. tulipifera (mean $\Psi_{\mathrm{L}}$ interquartile range $0.36 \pm 0.02 \mathrm{MPa}$ ) and $A$. saccharum (mean $\Psi_{\mathrm{L}}$ interquartile range $0.37 \pm 0.10 \mathrm{MPa}$ ), respectively. Across all stands, $\Psi_{\text {safety }}$ were smallest and often negative for $Q$. alba.The average slope of the regression between $\Psi_{\text {safety }}$ and $\Psi_{\mathrm{L}}$ interquartile range were $-3.80( \pm 0.32)$ and -4.92 $( \pm 0.40)$ for $\Psi_{\text {safety,P12 }}$ and $\Psi_{\text {safety,P50, respectively and was consistently negative across } 100 \text { bootstrapped }}$ simulations (Fig. S4). Age-independent analysis of variation in $\Psi_{\text {safety }}$ across the aridity gradient revealed that the lowest $\Psi_{\text {safety }}$ often occurred in the more arid regions of our study (e.g., MO and NC_E); nevertheless, the largest differences were associated with species (Fig. S5 \& Table S2). Overall, the degree of isohydricity was strongly linked to hydraulic safety across species and sites $\left(R^{2}=0.57, p=<0.001\right.$ and $R^{2}=0.61, p$ $=<0.001$ for $\Psi_{\text {safety,P12 }}$ and $\Psi_{\text {safety,P50, }}$, respectively), such that increasingly anisohydric behavior promoted 
greater risk for hydraulic damage (Fig. 7).

Estimated native embolism patterns were highly similar to $\Psi_{\text {safety }}$ (Fig. 8a). Q. alba had greater estimated native embolism than L. tulipifera and A. saccharum under field conditions (Species effect; $F_{n d f, d d f}=162.559$, $p=0.001$, Table 4). We detected some intra-species differences associated with stand age across regions (Species*Age*Region effect; $F_{n d f, d d f}=3.347, p=0.039$, Table 4). However, these differences were often inconsistent across regions (e.g., greater estimated native embolism with increasing stand age for $Q$. alba in IN and lower estimated native embolism with increasing stand age for $Q$. alba in NC_W, Fig. 8a) and may be due to non-overlapping $\Psi_{\mathrm{L}}$ sampling periods within chronosequences. Regardless, spatio-temporal effects (e.g., Species*Age*Region effect) were substantially more marginal than the large species effect (Table 4). Overall, increasing $\Psi_{\mathrm{L}}$ interquartile range across species and stands were strongly associated with a greater extent of estimated native embolism $\left(R^{2}=0.67, p=<0.001\right.$, Fig. 8b \& Fig. S6). This relationship additionally coincided with a lower magnitude of hydraulic conductivity. For example, in NC_E, estimatedin-situ $K_{\text {stem }}$ was $0.30( \pm 0.133) \mathrm{kg} \mathrm{m}^{-1} \mathrm{~s}^{-1} \mathrm{MPa}^{-1}$ for $Q$. alba while estimated in-situ $K_{\text {stem }}$ for L. tulipifera and $A$. saccharum were $1.12( \pm 0.15) \mathrm{kg} \mathrm{m}^{-1} \mathrm{~s}^{-1} \mathrm{MPa}^{-1}$ and $0.62( \pm 0.04) \mathrm{kg} \mathrm{m}^{-1} \mathrm{~s}^{-1} \mathrm{MPa}^{-1}$, respectively.

\section{Discussion}

We tested three hypotheses to assess variability and coordination of key plant hydraulic traits across ten deciduous forest stands. We found little support that stand age and hydroclimate influenced relative xylem vulnerability (hypothesis $1 \& 2$ ). While we detected some region and age effects, variation in vulnerability to embolism was principally determined by the large species effect. Additionally, we found little support for hypothesis 3 , which predicted stricter $\Psi_{\mathrm{L}}$ regulation would be associated more vulnerable xylem. Contrary to the prevailing expectation, we found that the more anisohydric $Q$. alba possessed stem tissues more vulnerable to embolism than their more isohydric counterparts. Moreover, we found that $Q$. alba had small or negative $\Psi_{\text {safety }}$ and a high degree of estimated native embolism such that its loose regulation of $\Psi_{\mathrm{L}}$ likely occurred with a substantial hydraulic cost.

7.1 Why were embolism thresholds invariant with climate and stand age?

Although P50 was impacted for some species by a combination of forest age and region, species was the predominant factor explaining variability in embolism vulnerability. This result, however, must be reconciled with the body of work demonstrating vegetation's capacity to acclimate xylem to pedo-climatic conditions (Awad et al ., 2010; Durante et al ., 2011; Gea-Izquierdo et al ., 2012). The clearest trends of acclimation are often found in manipulation studies (Beikircher \& Mayr, 2009; Awadet al ., 2010). However, surveys of hydraulic traits across species' ranges have found more ambiguous patterns (Martínez-Vilaltaet al ., 2009; Wortemann et al ., 2011; Charra-Vaskouet al ., 2012; Lamy et al ., 2014).

The similarity across climate observed here may be evidence that acclimation reflects a broader set of morphological changes to the whole-plant hydraulic architecture, rather than simple adjustments to stem xylem traits (Lamy et al ., 2014). Although we found little intra-species variation in stem anatomy across age class and sites, modifications of other traits may explain how Q. alba, L. tulipifera, and A. saccharum establish dominance across diverse climate ranges. These acclimations may include modifications to leaf:sapwood area ratio (Addington et al., 2006; Martínez-Vilatla et al ., 2009), root:leaf area ratio (Sperryet al ., 2002), fine root turnover (Meier \& Leuschner, 2008), or vulnerability of root tissues (Alder et al., 1996; Wolfe et al ., 2016).

These species may also rely on morphological changes to alleviate emerging hydraulic constraints as they mature. As canopies grow in height, greater xylem tension and pathlength resistance restricts hydraulic transport to canopy leaves (McDowell et al ., 2002; Novick et al ., 2009). To cope with these constraints, stem embolism resistance often increases with height in the canopy, indicative of acclimation (Burgess et al ., 2006; Ambrose et al ., 2009). Although age effects on embolism thresholds were minimal across stands, age also had little impact on $\Psi_{\mathrm{L}}$ decline. Thus, age-related constraints may have been mitigated through whole-plant adjustments that reduce damaging plant water potential gradients, rather than increased xylem resistance. 


\subsection{The perplexing case of Q. alba}

Our finding that $Q$. alba had the most vulnerable xylem was unexpected. Quercus species are often considered more drought tolerant than many co-dominants, attributed to their morphological and physiological adaptations that allow them to withstand soil moisture deficits (Abrams, 2003). Our results complicate this perspective. We found that $Q$. alba had particularly high P50 (consistent with previous work: Maherali et al ., 2006; Kannenberg et al.,2019) but were also more anisohydric. We used the variation in $\Psi_{\mathrm{L}}$ to quantify the degree of isohydricity in order to incorporate stomatal responses to both declining soil water and increasing $D$ , noting that the latter is the predominant factor limiting conductance for these sites and species (Novick et al., 2016; Yi et al., 2019; Denham et al., 2021). However, prior work using other approaches for quantifying isohydricity in these study sites and elsewhere also concludes that Quercus species are more anisohydric than many of their co-dominant counterparts (Abrams, 1990; Cavender-Barres \& Bazzaz, 2000; Ewers et al. , 2007; Meinzer et al., 2013; Roman et al., 2015; Kannenberg et al ., 2019). Here, our results further revealed that $Q$. alba trees had a high degree of estimated native embolism and negative $\Psi_{\text {safety }}$ suggesting they are remarkably vulnerable to drought.

While rooting depth is an important component of a plant's water use strategy, species-specific differences in rooting depth cannot explain our results. Quercus species tend to be more deeply rooted than cohabiting tree species in eastern US forests (Abrams, 1990), an expectation recently confirmed by our study team in IN 85yo (Lanninget al ., 2020). However, periodic observations of pre-dawn $\Psi_{\mathrm{L}}$, a commonly used proxy for integrated $\Psi_{\mathrm{S}}$ across the rooting zone (Richter, 1997), were less conclusive about the extent to which functional rooting depth varied across species (Table S3). In any event, if $Q$. alba have deeper roots, then access to more stable moisture pools should keep midday $\Psi_{\mathrm{L}}$ elevated relative to other species; instead, we find $Q$. alba typically had more negative midday $\Psi_{\mathrm{L}}$ (Fig. 6) despite the fact they may have access to deeper pools of water.

While the hydraulic metrics quantified here are widely used to characterize drought-susceptibility, drought impacts on whole-plant physiological function are more complex than stomatal regulation of xylem water tension. For example, drought-susceptibility is determined not only by the risk of xylem dysfunction, but also the plant's ability to cope with and recover from hydraulic damage (Meinzer \& McCulloh, 2013). We therefore consider how $Q$. alba can exhibit a seemingly risky hydraulic strategy while adhering to droughttolerance. First, we note that our methodology permits an evaluation of the vulnerability of the entire sapwood depth. However, it is not clear that $Q$. alba rely on the entire depth of sapwood to actively conduct water (Cochard \& Tyree, 1990). In a related study from IN 85yo, Yi et al . (2017) found that the inner sapwood of $Q$. alba conducted a more significant fraction of water during drought, with water transport largely restricted to outer rings during well-watered periods. Additionally, internal water storage can also play an important role in determining the relationship between leaf gas exchange and stem xylem traits. Ring-porous species are known to use smaller amounts of stored water than diffuse-porous species because of their low number of active rings (Köcher et al ., 2013). Q. alba has much higher wood density than either $L$. tulipifera or A. saccharum, and species with greater wood density tend to have low capacitance (e.g., Meinzer et al., 2008). Unlike L. tulipifera and A. saccharum that bear large sapwood volume and have low wood density, the small water storage capacity of $Q$. alba cannot provide enough water to limit the rapid drop in water potential due to stomatal water loss, which could also explain its anisohydric behavior (Matheny et al ., 2015).

Recovery from hydraulic impairment may also explain how $Q$. albatolerates drought while possessing vulnerable xylem. Refilling of embolized conduits is a possible strategy for ring-porous species to maintain hydraulic function (Brodersen et al ., 2010; Ogasaet al ., 2013; Trifilò et al ., 2019; Zeppel et al ., 2019), although whether xylem refilling routinely occurs in long vessel species is debated (Lamarque et al., 2018). Moreover, $Q$. alba bears only a few hydraulically active sapwood rings $(<10)$, with the newest rings being the most efficient at moving water (Phillips et al ., 1996). Therefore, Q. albacould potentially repair a $50 \%$ loss of conductivity in fewer than five years just by the production of new annual rings. While metabolically costly, growth and assimilation for Quercus species is often less sensitive to water stress than their 
more isohydric co-dominants (Elliott et al. , 2015; Roman et al., 2015; Au et al., 2020). Thus, the hydraulic strategy of $Q$. alba may be to maximize carbon assimilation at the risk of hydraulic impairment such that hydraulic function can be readily recovered through new growth.Quercus species also have an abundance of embolism-resistant vasicentric tracheids that can account for as much as $15 \%$ of hydraulic conductivity in stems (Percolla et al., 2021). These tracheid networks likely play an important role in sustaining water transport and growth when vulnerable vessels have embolized (Fontes \& Cavender-Bares, 2020).

Xylem vulnerability assessments must be conducted with care and a clear recognition of potential sources of methodological bias (Cochardet al., 2013, Johnson et al., 2018; Lobo et al.,2018). The air-injection technique used in this study remains the most popular tool for generating vulnerability curves, though it is sensitive to open vessel artifacts which may produce excessive variability in the derived estimates of P50 (MartinStPaul et al., 2014). As discussed extensively in our methods, we deployed a thorough set of quality control measures to minimize this source of error in our data. These measures included: [1] limiting samples to young, distal branches which have shorter vessels, [2] direct testing for the presence of open vessels on every sample using the air-infiltration technique, and [3] careful post-facto screening of curves to remove those that were conspicuously 'r-shaped'. If $Q$. alba samples were characterized by a greater number of open vessels, then we would have expected a high percentage of $Q$. alba curves to be 'r-shaped.' Instead, variability in P50 was similar across species (coefficient of variation $=0.26,0.19$, \& 0.19 for Q. alba, A. saccharumand L. tulipifera, respectively) suggesting that focusing on young branches and directly testing for open vessels were effective at limiting open vessel bias.

We recognize that this study focused only on three tree species and that others have found stomatal regulation and embolism vulnerability to be generally coordinated across species in other temperate regions (e.g., Vogt, 2001). Nonetheless, our results are consistent with other studies employing different strategies to generate 'sshaped' vulnerability curves for Quercus species. Using the cavitron technique, Loboet al., (2018) found that species-specific curves of six EuropeanQuercus species were highly consistent and sigmoidal when branches were screened for open vessels. Johnson et al., (2018) found good agreement between the air-injection and centrifuge methods for $Q$. fusiform branches when checked for open vessels, as they were in our study. Moreover, Kannenberg et al., (2019) used the air-injection technique to generate xylem vulnerability curves for the entire stem of tree saplings, which should be especially insensitive to open vessel artifacts; that study also concluded that the P50 of Q. alba was higher than L. tulipifera and A. saccharum. Finally, Skelton et al. (2021) used cutting edge techniques to visually monitor embolism formation. While they concluded that western North American Quercus species that dominate desert/chaparral environments have substantially negative P50s, they also reported that Quercus species growing in more temperate western forests have less negative P50 which were similar to those observed for the $Q$. alba trees growing in our temperate and mesic study sites (e.g., P50 [?] -3 MPa).

Altogether, it appears that $Q$. alba sustain high rates of gas exchange at the cost of operating with damaging water potential gradients and low $\Psi_{\text {safety }}$. Moreover, much of the variability in stomatal conductance and water potential for eastern US trees, and especially Quercus species, are determined by the dynamics of $D$ (Yi et al., 2019, Novick et al.,2019; Denham et al., 2021). Thus, these species may be particularly vulnerable to hydraulic dysfunction linked to future droughts that will be characterized by increasingly high $D$ (Ficklin \& Novick, 2017). In that regard, strategies to sustainQuercus dominated forest may need to recognize that they may in fact be quite sensitive to drought stress.

\subsection{Conclusion}

To mitigate hydraulic damage, many plant species adhere to a strict coordination between regulation of $\Psi_{\mathrm{L}}$ and vulnerability to embolism. However, we found that the $\Psi_{\mathrm{L}}$ behavior of $Q$. alba was not buffered by embolism resistant tissues to the same extent as co-occurring L. tulipifera and A. saccharumacross ten eastern US forests sites. These results highlight that important and abundant eastern US forest species have drought-response traits that are coordinated in a fundamentally different way than popular modeling frameworks (Naudts et al. , 2015; Sperry \& Love, 2015; Kennedy et al., 2019; Mirfenderesgi et al ., 2019). Moreover, we found that $Q$. alba sustains gas exchange at the cost of operating with damaging water potential 
gradients and low $\Psi_{\text {safety }}$ such that Quercus dominated forests may be vulnerable to shifting drought regimes (Ficklin \& Novick, 2017). Ultimately, our understanding of plant-water relations may be improved by further investigation into physiological mechanisms which allow plants to tolerate or recover from xylem dysfunction. Such mechanisms may be particularly important in temperate regions, where generally moisture-abundant conditions may facilitate embolism repair through regrowth following drought.

\section{Acknowledgements}

We thank D. Tyler Roman, Matthew K. Wenzel, Kathryn O. Shay, Michael P. Voyles, and Daniel C. Ishmael for assistance with data collection. We also thank Michael Spalding and Indiana Department of Natural Resource for access to Morgan-Monroe State Forest sampling locations. We acknowledge support from the USDA Forest Service, Southern Research Station, US Department of Energy, through the Terrestrial Ecosystem Science Program and the AmeriFlux Management Project, the National Science Foundation Division of Environmental Biology (grant DEB-1552747 and DEB-1637522) the Integrative Organismal System (IOS-1754893), and the USDA Agriculture and Food Research Initiative (grant 2017-67013-26191 and 2012-67019-19484). JDW acknowledges support for the MOFLUX (US-MOz) site from the U.S. Department of Energy, Office of Science, Office of Biological and Environmental Research Program, through Oak Ridge National Laboratory's Terrestrial Ecosystem Science Focus Area; ORNL is managed by UT-Battelle, LLC, for the U.S. DOE under contract DE-AC05-00OR22725. The authors declare no conflicts of interest.

\subsection{Author Contributions}

MCB and KAN designed the research. MCB, AOC, SOD, JCD, DMJ, JEM, and JDW collected data and preformed laboratory analysis. MCB, KAN, JCD, and CFM analyzed the data. MCB and KAN wrote the manuscript with input and revisions from all co-authors.

\section{References}

Abrams, M. D. (1990). Adaptations and responses to drought in Quercus species of North America. Tree physiology $7,227-238$.

Abrams, M. D. (2003). Where has all the white oak gone?. BioScience 53, 927-939.

Addington, R. N., Donovan, L. A., Mitchell, R. J., et al. (2006). Adjustments in hydraulic architecture of Pinus palustris maintain similar stomatal conductance in xeric and mesic habitats. Plant, Cell \& Environment 29, 535-545.

Alder, N. N., Sperry, J. S., \& Pockman, W. T. (1996). Root and stem xylem embolism, stomatal conductance, and leaf turgor in Acer grandidentatum populations along a soil moisture gradient. Oecologia 105, 293-301.

Ambrose, A. R., Sillett, S. C., \& Dawson, T. E. (2009). Effects of tree height on branch hydraulics, leaf structure and gas exchange in California redwoods. Plant, Cell $\&$ Environment 32,743-757.

Anderegg, W. R. (2015). Spatial and temporal variation in plant hydraulic traits and their relevance for climate change impacts on vegetation. New Phytologist 205, 1008-1014.

Au, T. F., Maxwell, J. T., Novick, K. A., et al. (2020). Demographic shifts in eastern US forests increase the impact of late-season drought on forest growth. Ecography , 43,1475-1486.

Awad, H., Barigah, T., Badel, E., Cochard, H., \& Herbette, S. (2010). Poplar vulnerability to xylem cavitation acclimates to drier soil conditions. Physiologia Plantarum 139, 280-288.

Beikircher, B., \& Mayr, S. (2009). Intraspecific differences in drought tolerance and acclimation in hydraulics of Ligustrum vulgare and Viburnum lantana. Tree Physiology 29, 765-775.

Bhaskar, R., \& Ackerly, D. D. (2006). Ecological relevance of minimum seasonal water potentials. Physiologia Plantarum 127,353-359. 
Bond, B. J., \& Kavanagh, K. L. (1999). Stomatal behavior of four woody species in relation to leaf-specific hydraulic conductance and threshold water potential. Tree Physiology 19, 503-510.

Brodersen, C. R., McElrone, A. J., Choat, B., Matthews, M. A., \& Shackel, K. A. (2010). The dynamics of embolism repair in xylem: in vivo visualizations using high-resolution computed tomography. Plant physiology 154, 1088-1095.

Buckley, T. N. (2005). The control of stomata by water balance. New phytologist 168, 275-292.

Burgess, S. S., Pittermann, J., \& Dawson, T. E. (2006). Hydraulic efficiency and safety of branch xylem increases with height in Sequoia sempervirens (D. Don) crowns. Plant, Cell \& Environment 29, 229-239.

Cavender-Bares, J., \& Bazzaz, F. A. (2000). Changes in drought response strategies with ontogeny in Quercus rubra: implications for scaling from seedlings to mature trees. Oecologia 124, 8-18.

Cavender-Bares, J. (2016). Diversity, distribution and ecosystem services of the North American oaks. International oaks 27, 37-48.

Cavender-Bares, J. (2019). Diversification, adaptation, and community assembly of the American oaks (Quercus), a model clade for integrating ecology and evolution. New Phytologist 221, 669-692.

Charra-Vaskou, K., Charrier, G., Wortemann, R., et al. (2012). Drought and frost resistance of trees: a comparison of four species at different sites and altitudes. Annals of Forest Science 69, 325-333.

Choat, B., Drayton, W. M., Brodersen, C., Matthews, et al.(2010). Measurement of vulnerability to water stress-induced cavitation in grapevine: a comparison of four techniques applied to a long-vesseled species. Plant, Cell \& Environment 33, 1502-1512.

Choat, B., Jansen, S., Brodribb, T. J., et al. (2012). Global convergence in the vulnerability of forests to drought. Nature 491, 752-755.

Cochard, H., \& Tyree, M. T. (1990). Xylem dysfunction in Quercus: vessel sizes, tyloses, cavitation and seasonal changes in embolism. Tree Physiology 6, 393-407.

Cochard, H., Herbette, S., Barigah, T., et al. (2010). Does sample length influence the shape of xylem embolism vulnerability curves? A test with the Cavitron spinning technique. Plant, Cell \& Environment 33, 1543-1552.

Cochard, H., Badel, E., Herbette, S., et al. (2013). Methods for measuring plant vulnerability to cavitation: a critical review. Journal of Experimental Botany 64, 4779-4791.

Dai, A. (2011). Drought under global warming: a review. Wiley Interdisciplinary Reviews: Climate Change 2, 45-65.

Davis, S. D., Sperry, J. S., \& Hacke, U. G. (1999). The relationship between xylem conduit diameter and cavitation caused by freezing. American journal of botany 86, 1367-1372.

Delzon, S., \& Cochard, H. (2014). Recent advances in tree hydraulics highlight the ecological significance of the hydraulic safety margin. New Phytologist 203, 355-358.

Denham, S. O., Oishi, A. C., Miniat, C. F., et al. (2021). Eastern US deciduous tree species respond dissimilarly to declining soil moisture but similarly to rising evaporative demand. Tree Physiology $\mathbf{4 1}$, 944-959.

Dietze, M. C., \& Moorcroft, P. R. (2011). Tree mortality in the Eastern and central United States: patterns and drivers. Global Change Biology 17, 3312-3326.

Domec, J. C., \& Gartner, B. L. (2001). Cavitation and water storage capacity in bole xylem segments of mature and young Douglas-fir trees. Trees 15, 204-214. 
Domec, J. C., \& Johnson, D. M. (2012). Does homeostasis or disturbance of homeostasis in minimum leaf water potential explain the isohydric versus anisohydric behavior of Vitis vinifera L. cultivars?. Tree physiology 32, 245-248.

Domec, J. C., Ogée, J., Noormets, A., et al. (2012). Interactive effects of nocturnal transpiration and climate change on the root hydraulic redistribution and carbon and water budgets of southern United States pine plantations. Tree Physiology 32, 707-723.

Durante, M., Maseda, P. H., \& Fernandez, R. J. (2011). Xylem efficiency vs. safety: Acclimation to drought of seedling root anatomy for six Patagonian shrub species. Journal of arid environments 75, 397-402.

Elliott, K. J., \& Swank, W. T. (1994). Impacts of drought on tree mortality and growth in a mixed hardwood forest. Journal of Vegetation Science 5, 229-236.

Elliott, K. J., Miniat, C. F., Pederson, N., \& Laseter, S. H. (2015). Forest tree growth response to hydroclimate variability in the southern Appalachians. Global Change Biology 21, 4627-4641.

Ewers, B. E., Mackay, D. S., \& Samanta, S. (2007). Interannual consistency in canopy stomatal conductance control of leaf water potential across seven tree species. Tree Physiology 27,11-24.

Fei, S., Kong, N., Steiner, K. C., et al. (2011). Change in oak abundance in the Eastern United States from 1980 to 2008. Forest Ecology and Management 262, 1370-1377.

Ficklin, D. L., \& Novick, K. A. (2017). Historic and projected changes in vapor pressure deficit suggest a continental-scale drying of the United States atmosphere. Journal of Geophysical Research: Atmospheres 122, 2061-2079.

Flory, S. L., \& Clay, K. (2010). Non-native grass invasion suppresses forest succession. Oecologia 164, 1029-1038.

Fontes, C. G., \& Cavender-Bares, J. (2020). Toward an integrated view of the 'elephant': unlocking the mysteries of water transport and xylem vulnerability in oaks. Tree physiology 40, 1-4.

Garcia-Forner, N., Biel, C., Save, R., \& Martinez-Vilalta, J. (2017). Isohydric species are not necessarily more carbon limited than anisohydric species during drought. Tree physiology 37,441-455.

Gea-Izquierdo, G., Fonti, P., Cherubini, P., et al. (2012). Xylem hydraulic adjustment and growth response of Quercus canariensis Willd. to climatic variability. Tree Physiology 32, 401-413.

Gu, L., Pallardy, S. G., Hosman, K. P., \& Sun, Y. (2015). Drought-influenced mortality of tree species with different predawn leaf water dynamics in a decade-long study of a central US forest. Biogeosciences 12, 2831-2845.

Gu, L., Pallardy, S. G., Yang, B., et al. (2016). Testing a land model in ecosystem functional space via a comparison of observed and modeled ecosystem flux responses to precipitation regimes and associated stresses in a Central US forest. Journal of Geophysical Research: Biogeosciences 121, 1884-1902.

Herbette, S., Wortemann, R., Awad, H., et al. (2010). Insights into xylem vulnerability to cavitation in Fagus sylvatica L.: phenotypic and environmental sources of variability. Tree physiology 30, 1448-1455.

Hochberg, U., Rockwell, F. E., Holbrook, N. M., \& Cochard, H. (2018). Iso/anisohydry: a plant-environment interaction rather than a simple hydraulic trait. Trends in Plant Science 23, 112-120.

Holtzman, N. M., Anderegg, L. D., Kraatz, S., et al. . (2021). L-band vegetation optical depth as an indicator of plant water potential in a temperate deciduous forest stand. Biogeosciences 18, 739-753.

Iverson, L. R., Prasad, A. M., Matthews, S. N., \& Peters, M. (2008). Estimating potential habitat for 134 eastern US tree species under six climate scenarios. Forest ecology and management 254, 390-406. 
Johnson, D. M., Wortemann, R., McCulloh, K. A., et al. (2016). A test of the hydraulic vulnerability segmentation hypothesis in angiosperm and conifer tree species. Tree physiology 36,983-993.

Johnson, D. M., Domec, J. C., Carter Berry, Z., et al. (2018). Co-occurring woody species have diverse hydraulic strategies and mortality rates during an extreme drought. Plant, Cell E Environment 41, 576-588.

Kannenberg, S. A., Novick, K. A., \& Phillips, R. P. (2019). Anisohydric behavior linked to persistent hydraulic damage and delayed drought recovery across seven North American tree species. New Phytologist 222, 1862-1872.

Kennedy, D., Swenson, S., Oleson, K. W., et al. (2019). Implementing plant hydraulics in the community land model, version 5. Journal of Advances in Modeling Earth Systems 11,485-513.

Klein, T. (2014). The variability of stomatal sensitivity to leaf water potential across tree species indicates a continuum between isohydric and anisohydric behaviours. Functional ecology 28,1313-1320.

Kocher, P., Horna, V., \& Leuschner, C. (2013). Stem water storage in five coexisting temperate broad-leaved tree species: significance, temporal dynamics and dependence on tree functional traits. Tree physiology 33, 817-832.

Konings, A. G., \& Gentine, P. (2017). Global variations in ecosystem-scale isohydricity. Global change biology 23,891-905.

Lamarque, L. J., Corso, D., Torres-Ruiz, J. M., et al. (2018). An inconvenient truth about xylem resistance to embolism in the model species for refilling Laurus nobilis L. Annals of Forest Science 75, 1-15.

Lamy, J. B., Delzon, S., Bouche, P. S., et al . (2014). Limited genetic variability and phenotypic plasticity detected for cavitation resistance in a Mediterranean pine. New Phytologist 201,874-886.

Lanning, M., Wang, L., Benson, M., et al. (2020). Canopy isotopic investigation reveals different water uptake dynamics of maples and oaks. Phytochemistry 175, 112389.

Leach, J. E., Woodhead, T., \& Day, W. (1982). Bias in pressure chamber measurements of leaf water potential. Agricultural Meteorology 27, 257-263.

Li, X., Blackman, C. J., Peters, J. M., et al . (2019). More than iso/anisohydry: hydroscapes integrate plant water use and drought tolerance traits in 10 eucalypt species from contrasting climates. Functional Ecology 33, 1035-1049.

Lobo, A., Torres-Ruiz, J. M., Burlett, R., et al . (2018). Assessing inter-and intraspecific variability of xylem vulnerability to embolism in oaks. Forest ecology and management 424,53-61.

Macalady, A. K., \& Bugmann, H. (2014). Growth-mortality relationships in pinon pine (Pinus edulis) during severe droughts of the past century: shifting processes in space and time. PloS one 9,e92770.

Maherali, H., \& DeLucia, E. H. (2000). Xylem conductivity and vulnerability to cavitation of ponderosa pine growing in contrasting climates. Tree Physiology 20, 859-867.

Maherali, H., Moura, C. F., Caldeira, M. C., et al . (2006). Functional coordination between leaf gas exchange and vulnerability to xylem cavitation in temperate forest trees. Plant, Cell \& Environment 29, 571-583.

Martin-StPaul, N. K., Longepierre, D., Huc, R., et al . (2014). How reliable are methods to assess xylem vulnerability to cavitation? The issue of 'open vessel'artifact in oaks. Tree physiology 34, 894-905.

Martinez-Vilalta, J., Cochard, H., Mencuccini, M., et al. (2009). Hydraulic adjustment of Scots pine across Europe. New Phytologist 184, 353-364.

Martinez-Vilalta, J., Poyatos, R., Aguade, D., et al. (2014). A new look at water transport regulation in plants. New phytologist 204, 105-115. 
Martinez-Vilalta, J., \& Garcia-Forner, N. (2017). Water potential regulation, stomatal behaviour and hydraulic transport under drought: deconstructing the iso/anisohydric concept. Plant, Cell \& Environment 40, 962-976.

Martinez-Vilalta, J., Santiago, L. S., Poyatos, R., et al.(2021). Towards a statistically robust determination of minimum water potential and hydraulic risk in plants. New Phytologist, in press.

Matheny, A. M., Bohrer, G., Garrity, S. R., et al. (2015). Observations of stem water storage in trees of opposing hydraulic strategies. Ecosphere 6, 1-13.

Matheny, A. M., Fiorella, R. P., Bohrer, G., et al. (2017). Contrasting strategies of hydraulic control in two codominant temperate tree species. Ecohydrology 10, e1815.

McDowell, N., Barnard, H., Bond, B., et al. (2002). The relationship between tree height and leaf area: sapwood area ratio. Oecologia 132, 12-20.

McDowell, N., Pockman, W. T., Allen, C. D., et al. (2008). Mechanisms of plant survival and mortality during drought: why do some plants survive while others succumb to drought?. New phytologist 178, 719-739.

McEwan, R. W., Dyer, J. M., \& Pederson, N. (2011). Multiple interacting ecosystem drivers: toward an encompassing hypothesis of oak forest dynamics across eastern North America. Ecography 34,244-256.

Meddens, A. J., Hicke, J. A., Macalady, A. K., et al. (2015). Patterns and causes of observed pinon pine mortality in the southwestern United States. New Phytologist 206, 91-97.

Meier, I. C., \& Leuschner, C. (2008). Genotypic variation and phenotypic plasticity in the drought response of fine roots of European beech. Tree physiology 28, 297-309.

Meinzer, F. C., Campanello, P. I., Domec, J. C., et al. (2008). Constraints on physiological function associated with branch architecture and wood density in tropical forest trees. Tree Physiology 28, 16091617.

Meinzer, F. C., \& McCulloh, K. A. (2013). Xylem recovery from drought-induced embolism: where is the hydraulic point of no return?. Tree physiology 33, 331-334.

Meinzer, F. C., Woodruff, D. R., Eissenstat, D. M., et al . (2013). Above-and belowground controls on water use by trees of different wood types in an eastern US deciduous forest. Tree physiology 33, 345-356.

Meinzer, F. C., Woodruff, D. R., Marias, D. E., et al. (2014). Dynamics of leaf water relations components in co-occurring iso-and anisohydric conifer species. Plant, Cell $\mathcal{E}\}$ Environment 37, 2577-2586.

Meinzer, F. C., Woodruff, D. R., Marias, et al. (2016). Mapping 'hydroscapes' along the iso-to anisohydric continuum of stomatal regulation of plant water status. Ecology letters 19,1343-1352.

Meinzer, F. C., Smith, D. D., Woodruff, D. R., et al. (2017). Stomatal kinetics and photosynthetic gas exchange along a continuum of isohydric to anisohydric regulation of plant water status. Plant, cell $\mathscr{E}$ environment 40, 1618-1628.

Mirfenderesgi, G., Matheny, A. M., \& Bohrer, G. (2019). Hydrodynamic trait coordination and cost-benefit trade-offs throughout the isohydric-anisohydric continuum in trees. Ecohydrology 12, e2041.

Naudts, K., Ryder, J., McGrath, M. J., et al. (2015). A vertically discretised canopy description for ORCHIDEE (SVN r2290) and the modifications to the energy, water and carbon fluxes. Geoscientific Model Development 8, 2035-2065.

Novick, K., Oren, R., Stoy, P., et al. (2009). The relationship between reference canopy conductance and simplified hydraulic architecture. Advances in Water Resources 32, 809-819. 
Novick, K. A., Ficklin, D. L., Stoy, P. C., et al. (2016). The increasing importance of atmospheric demand for ecosystem water and carbon fluxes. Nature climate change 6, 1023-1027.

Novick, K. A., Konings, A. G., \& Gentine, P. (2019). Beyond soil water potential: An expanded view on isohydricity including land-atmosphere interactions and phenology. Plant, cell $\&$ s environment 42, 18021815 .

Ogasa, M., Miki, N. H., Murakami, Y., \& Yoshikawa, K. (2013). Recovery performance in xylem hydraulic conductivity is correlated with cavitation resistance for temperate deciduous tree species. Tree physiology 33, 335-344.

Oishi, A. C., Oren, R., Novick, K. A., et al. (2010). Interannual invariability of forest evapotranspiration and its consequence to water flow downstream. Ecosystems 13, 421-436.

Oishi, A. C., Miniat, C. F., Novick, K. A., et al. (2018). Warmer temperatures reduce net carbon uptake, but do not affect water use, in a mature southern Appalachian forest. Agricultural and forest meteorology 252, 269-282.

Olivier, M. D., Robert, S., \& Fournier, R. A. (2016). Response of sugar maple (Acer saccharum, Marsh.) tree crown structure to competition in pure versus mixed stands. Forest Ecology and Management 374, 20-32.

Pan, Y., Chen, J. M., Birdsey, R., et al. (2011). Age structure and disturbance legacy of North American forests. Biogeosciences8, 715-732.

Peguero-Pina, J. J., Mendoza-Herrer, O., Gil-Pelegrin, E., \& Sancho-Knapik, D. (2018). Cavitation limits the recovery of gas exchange after severe drought stress in holm oak (Quercus ilex L.). Forests 9, 443.

Percolla, M. I., Fickle, J. C., Rodriguez-Zaccaro, F. D., et al.(2021). Hydraulic function and conduit structure in the xylem of five oak species. IAWA Journal 1, 1-20.

Phillips, N., Oren, R., \& Zimmermann, R. (1996). Radial patterns of xylem sap flow in non-, diffuse-and ring-porous tree species. Plant, Cell \& Environment 19, 983-990.

Plaut, J. A., Yepez, E. A., Hill, J., et al. (2012). Hydraulic limits preceding mortality in a pinon-juniper woodland under experimental drought. Plant, Cell \& Environment 35,1601-1617.

Richter, H. (1997). Water relations of plants in the field: some comments on the measurement of selected parameters. Journal of Experimental Botany 48, 1-7.

Roman, D. T., Novick, K. A., Brzostek, E. R., et al. (2015). The role of isohydric and anisohydric species in determining ecosystem-scale response to severe drought. Oecologia 179, 641-654.

Scholz, A., Klepsch, M., Karimi, Z., \& Jansen, S. (2013). How to quantify conduits in wood?. Frontiers in plant science $\mathbf{4}, 56$.

Schultz, H. R. (2003). Differences in hydraulic architecture account for near-isohydric and anisohydric behaviour of two field-grown Vitis vinifera L. cultivars during drought. Plant, Cell 85 Environment 26, 1393-1405.

Simonin, K. A., Burns, E., Choat, B., et al . (2015). Increasing leaf hydraulic conductance with transpiration rate minimizes the water potential drawdown from stem to leaf. Journal of Experimental Botany 66, 13031315 .

Skelton, R. P., West, A. G., \& Dawson, T. E. (2015). Predicting plant vulnerability to drought in biodiverse regions using functional traits. Proceedings of the National Academy of Sciences 112, 5744-5749.

Skelton, R. P., Dawson, T. E., Thompson, S. E., et al. (2018). Low vulnerability to xylem embolism in leaves and stems of North American oaks. Plant Physiology 177, 1066-1077. 
Skelton, R. P., Anderegg, L. D., Diaz, J., et al. (2021). Evolutionary relationships between drought-related traits and climate shape large hydraulic safety margins in western North American oaks. Proceedings of the National Academy of Sciences

118.

Sperry, J. S., \& Sullivan, J. E. (1992). Xylem embolism in response to freeze-thaw cycles and water stress in ring-porous, diffuse-porous, and conifer species. Plant physiology $100,605-613$.

Sperry, J. S., \& Saliendra, N. Z. (1994). Intra-and inter-plant variation in xylem cavitation in Betula occidentalis. Plant, Cell \& Environment 17, 1233-1241.

Sperry, J. S., Hacke, U. G., Oren, R., \& Comstock, J. P. (2002). Water deficits and hydraulic limits to leaf water supply. Plant, cell \& environment 25, 251-263.

Sperry, J. S., \& Love, D. M. (2015). What plant hydraulics can tell us about responses to climate-change droughts. New Phytologist 207, 14-27.

Swank, W. T., \& Webster, J. R. (Eds.). (2014). Long-term response of a forest watershed ecosystem: Clearcutting in the southern Appalachians. Oxford University Press, New York.

Taneda, H., \& Sperry, J. S. (2008). A case-study of water transport in co-occurring ring-versus diffuseporous trees: contrasts in water-status, conducting capacity, cavitation and vessel refilling. Tree physiology 28, 1641-1651.

Tardieu, F., \& Simonneau, T. (1998). Variability among species of stomatal control under fluctuating soil water status and evaporative demand: modelling isohydric and anisohydric behaviours. Journal of experimental botany 49, 419-432.

Torres-Ruiz, J. M., Cochard, H., Mayr, S., et al. (2014). Vulnerability to cavitation in Olea europaea current-year shoots: further evidence of an open-vessel artifact associated with centrifuge and air-injection techniques. Physiologia Plantarum 152,465-474.

Trabucco, A., \& Zomer, R. J. (2009). Global aridity index (global-aridity) and global potential evapotranspiration (global-PET) geospatial database. CGIAR Consortium for Spatial Information .

Trifilo, P., Kiorapostolou, N., Petruzzellis, F., et al. (2019). Hydraulic recovery from xylem embolism in excised branches of twelve woody species: Relationships with parenchyma cells and non-structural carbohydrates. Plant Physiology and Biochemistry 139, 513-520.

Turner, N. C. (1988). Measurement of plant water status by the pressure chamber technique. Irrigation science 9, 289-308.

Tyree, M. T., \& Sperry, J. S. (1989). Vulnerability of xylem to cavitation and embolism. Annual review of plant biology 40, 19-36.

Tyree, M. T., \& Zimmermann, M. H. (2013). Xylem structure and the ascent of sap . Springer, Berlin, Germany.

Vogt, U. K. (2001). Hydraulic vulnerability, vessel refilling, and seasonal courses of stem water potential of Sorbus aucuparia L. and Sambucus nigra L. Journal of Experimental Botany 52 , 1527-1536.

Wheeler, J. K., Huggett, B. A., Tofte, A. N., Rockwell, F. E., \& Holbrook, N. M. (2013). Cutting xylem under tension or supersaturated with gas can generate PLC and the appearance of rapid recovery from embolism. Plant, Cell \& Environment 36, 1938-1949.

Williams, L. E., \& Araujo, F. J. (2002). Correlations among predawn leaf, midday leaf, and midday stem water potential and their correlations with other measures of soil and plant water status in Vitis vinifera. Journal of the American Society for Horticultural Science 127, 448-454. 
Wolfe, B. T., Sperry, J. S., \& Kursar, T. A. (2016). Does leaf shedding protect stems from cavitation during seasonal droughts? A test of the hydraulic fuse hypothesis. New Phytologist 212,1007-1018.

Wood, J. D., Knapp, B. O., Muzika, R. M., et al. (2018). The importance of drought-pathogen interactions in driving oak mortality events in the Ozark Border Region. Environmental Research Letters 13, 015004.

Wortemann, R., Herbette, S., Barigah, T. S., et al. (2011). Genotypic variability and phenotypic plasticity of cavitation resistance in Fagus sylvatica L. across Europe. Tree physiology 31,1175-1182.

Wu, G., Guan, K., Li, Y., Novick, K. A., et al. (2021). Interannual variability of ecosystem iso/anisohydry is regulated by environmental dryness. New Phytologist 229, 2562-2575.

Yi, K., Dragoni, D., Phillips, R. P., et al. (2017). Dynamics of stem water uptake among isohydric and anisohydric species experiencing a severe drought. Tree physiology 37, 1379-1392.

Yi, K., Maxwell, J. T., Wenzel, M. K., et al. (2019). Linking variation in intrinsic water-use efficiency to isohydricity: a comparison at multiple spatiotemporal scales. New Phytologist 221, 195-208.

Zeppel, M. J., Anderegg, W. R., Adams, H. D., et al. (2019). Embolism recovery strategies and nocturnal water loss across species influenced by biogeographic origin. Ecology and evolution 9, 5348-5361.

Zhang, Y. J., Meinzer, F. C., Qi, J. H., et al . (2013). Midday stomatal conductance is more related to stem rather than leaf water status in subtropical deciduous and evergreen broadleaf trees. Plant, cell $\mathscr{E}$ environment 36, 149-158.

10. Tables

Table 1. Climate and sampled tree species across the ten forest sites. Values in parentheses are one standard deviation.

\begin{tabular}{|c|c|c|c|c|c|c|c|c|}
\hline Region & Stand & $\begin{array}{l}\text { Species } \\
\text { Sampled }\end{array}$ & $\begin{array}{l}\text { Canopy } \\
\text { Height } \\
(\mathbf{m})\end{array}$ & $\begin{array}{l}\text { Aridity } \\
\text { Wet- } \\
\text { nessIn- } \\
\text { dex }\end{array}$ & $\begin{array}{l}\text { Annual } \\
\text { Precipi- } \\
\text { tation } \\
(\mathrm{mm})\end{array}$ & $\begin{array}{l}\text { Growing } \\
\text { Season } \\
\text { Precipi- } \\
\text { tation } \\
(\mathrm{mm})\end{array}$ & $\begin{array}{l}\text { Annual } \\
\text { Temper- } \\
\text { ature } \\
(0 \mathrm{C})\end{array}$ & $\begin{array}{l}\text { Growing } \\
\text { Season } \\
\text { Temper- } \\
\text { ature } \\
(0 \mathrm{C})\end{array}$ \\
\hline \multirow[t]{3}{*}{ NC_W } & $15 y o$ & $\begin{array}{l}\text { L. } \\
\text { tulip- } \\
\text { ifera, } \\
\text { Q. alba }\end{array}$ & 4.5 & 1.478 & $\begin{array}{l}1723.4 \\
(378.2)\end{array}$ & $\begin{array}{l}795 \\
(238.2)\end{array}$ & $\begin{array}{l}13.7 \\
(0.5)\end{array}$ & $\begin{array}{l}19.7 \\
(0.5)\end{array}$ \\
\hline & 35 yo & $\begin{array}{l}\text { L. } \\
\text { tulip- } \\
\text { ifera, } \\
\text { Q. alba }\end{array}$ & 17 & & & & & \\
\hline & 85 yo & $\begin{array}{l}\text { L. } \\
\text { tulip- } \\
\text { ifera, } \\
\text { Q. alba }\end{array}$ & 35 & & & & & \\
\hline \multirow[t]{2}{*}{ IN } & $15 y o$ & $\begin{array}{l}\text { L. } \\
\text { tulip- } \\
\text { ifera, } \\
\text { Q. alba }\end{array}$ & 5 & 0.928 & $\begin{array}{l}1081.2 \\
(180.7)\end{array}$ & $\begin{array}{l}600.7 \\
(128.3)\end{array}$ & $\begin{array}{l}12.7 \\
(1.1)\end{array}$ & $\begin{array}{l}20.3 \\
(0.8)\end{array}$ \\
\hline & 35 yo & $\begin{array}{l}\text { L. } \\
\text { tulip- } \\
\text { ifera, } \\
\text { Q. alba }\end{array}$ & 20 & & & & & \\
\hline
\end{tabular}




\begin{tabular}{|c|c|c|c|c|c|c|c|c|}
\hline Region & Stand & $\begin{array}{l}\text { Species } \\
\text { Sampled }\end{array}$ & $\begin{array}{l}\text { Canopy } \\
\text { Height } \\
(\mathrm{m})\end{array}$ & $\begin{array}{l}\text { Aridity } \\
\text { Wet- } \\
\text { nessIn- } \\
\text { dex }\end{array}$ & $\begin{array}{l}\text { Annual } \\
\text { Precipi- } \\
\text { tation } \\
(\mathrm{mm})\end{array}$ & $\begin{array}{l}\text { Growing } \\
\text { Season } \\
\text { Precipi- } \\
\text { tation } \\
(\mathrm{mm})\end{array}$ & $\begin{array}{l}\text { Annual } \\
\text { Temper- } \\
\text { ature } \\
(0 \mathrm{C})\end{array}$ & $\begin{array}{l}\text { Growing } \\
\text { Season } \\
\text { Temper- } \\
\text { ature } \\
(\text { (0C) }\end{array}$ \\
\hline & 85 yo & $\begin{array}{l}A . \\
\text { saccha- } \\
\text { rum, } \\
\text { L. } \\
\text { tulip- } \\
\text { ifera, } \\
\text { Q. alba }\end{array}$ & 30 & & & & & \\
\hline \multirow[t]{3}{*}{ NC_E } & $15 y o$ & $\begin{array}{l}\text { A. } \\
\text { saccha- } \\
\text { rum }\end{array}$ & 9.2 & 0.811 & $\begin{array}{l}936.5 \\
(393.5)\end{array}$ & $\begin{array}{l}501.7 \\
(230.8)\end{array}$ & $\begin{array}{l}13.4 \\
(5.8)\end{array}$ & $\begin{array}{l}18.9 \\
(7.1)\end{array}$ \\
\hline & 35 yo & $\begin{array}{l}\text { A. } \\
\text { saccha- } \\
\text { rum, } \\
\text { L. } \\
\text { tulip- } \\
\text { ifera, } \\
\text { Q. alba }\end{array}$ & 15.1 & & & & & \\
\hline & 85 yo & $\begin{array}{l}\text { L. } \\
\text { tulip- } \\
\text { ifera, } \\
\text { Q. alba }\end{array}$ & 27.5 & & & & & \\
\hline MO & 85 yo & $\begin{array}{l}\text { A. } \\
\text { saccha- } \\
\text { rum, } \\
\text { Q. alba }\end{array}$ & 18.5 & 0.744 & $\begin{array}{l}897.7 \\
(225.9)\end{array}$ & $\begin{array}{l}537.5 \\
(186.6)\end{array}$ & $\begin{array}{l}13.7 \\
(1.1)\end{array}$ & $\begin{array}{l}21.4 \\
(0.9)\end{array}$ \\
\hline
\end{tabular}

Table 2. Statistics of test between subjects for vulnerability thresholds from two-way ANOVA with species and age as fixed factors and region as a blocking factor.

\begin{tabular}{llllll}
\hline & Dependent Variable & df & Mean Square & F & $\mathrm{p}$ \\
\hline Species & P12 & 2 & 17.033 & $\mathbf{1 4 9 . 8 7}$ & $\mathbf{0 . 0 0 1}$ \\
Age & P12 & 2 & 0.46 & 0.40 & 0.702 \\
Region & P12 & 3 & 0.444 & 0.37 & 0.784 \\
Species*Age & P12 & 2 & 0.018 & 0.07 & 0.935 \\
Species*Region & P12 & 3 & 0.113 & 0.05 & 0.727 \\
Age*Region & P12 & 3 & 1.229 & 4.81 & 0.115 \\
Species*Age*Region & P12 & 3 & 0.255 & 0.61 & 0.611 \\
Species & P50 & 2 & 33.719 & $\mathbf{1 6 9 . 6 2}$ & $\mathbf{0 . 0 0 3}$ \\
Age & P50 & 2 & 0.545 & 0.49 & 0.656 \\
Region & P50 & 3 & 0.556 & 0.37 & 0.78 \\
Species*Age & P50 & 2 & 0.058 & $\mathbf{1 8 . 8 8}$ & $\mathbf{0 . 0 1 7}$ \\
Age*Region & P50 & 3 & 1.21 & $\mathbf{2 1 . 3 1}$ & $\mathbf{0 . 0 1 6}$ \\
Species*Age*Region & P50 & 3 & 0.057 & 0.10 & 0.959 \\
\hline
\end{tabular}


Table 3. Statistics of test between subjects for xylem anatomy from two-way ANOVA with species and age as fixed factors.

\begin{tabular}{llllll}
\hline & Dependent Variable & df & Mean Square & $\mathrm{F}$ & $\mathrm{p}$ \\
\hline Species & Vessel Lumen Area & 2 & 1189744 & $\mathbf{1 2 4 . 3 7}$ & $<\mathbf{0 . 0 0 1}$ \\
Age & Vessel Lumen Area & 2 & 249.96 & 0.026 & 0.974 \\
Species*Age & Vessel Lumen Area & 3 & 2411.8 & 0.252 & 0.86 \\
Species & Vessel Density & 2 & 7932449 & $\mathbf{2 0 8 . 9 8 2}$ & $<\mathbf{0 . 0 0 1}$ \\
Age & Vessel Density & 2 & 73537 & 1.937 & 0.152 \\
Species*Age & Vessel Density & 3 & 95316.1 & 2.537 & 0.063 \\
\hline
\end{tabular}

Table 4. Statistics of test between subjects for estimated native embolism from two-way ANOVA with species and age as fixed factors and region as a blocking factor.

\begin{tabular}{llllll}
\hline & Dependent Variable & df & Mean Square & F & $\mathrm{p}$ \\
\hline Species & Native Embolism & 2 & 27686.67 & $\mathbf{1 6 2 . 5 5 9}$ & $\mathbf{0 . 0 0 1}$ \\
Age & Native Embolism & 2 & 25.08 & 0.022 & 0.979 \\
Region & Native Embolism & 3 & 562.93 & 0.807 & 0.754 \\
Species*Age & Native Embolism & 2 & 486.25 & 0.672 & 0.598 \\
Species*Region & Native Embolism & 3 & 166.72 & 0.202 & 0.887 \\
Age*Region & Native Embolism & 3 & 1168.99 & 1.598 & 0.385 \\
Species*Age*Region & Native Embolism & 3 & 731.335 & 3.347 & $\mathbf{0 . 0 3 9}$ \\
\hline
\end{tabular}

11. Figure Legends

Figure 1. Stand regions and moisture conditions across eastern United States deciduous forests. Aridity index values are mean Aridity Wetness Index (calculated as the fraction of mean annual precipitation to mean annual evapotranspiration) at $9 \mathrm{~m}$ spatial resolution from 1970-2000. Aridity index data were accessed from the CGIAR-CSI GeoPortal at https://cgiarcsi.community (Trabucco 8 Zomer, 2009).

Figure 2. Embolism thresholds across forest stands. Panel (a) and (b) are mean P12 and P50 values ( $\pm S E)$, respectively. Numbers above bars are sample size. Groups of bars not sharing the same uppercase letters denote significant differences among species determined by a two-way ANOVA with species and age as fixed factors and region as a blocking factor (Table 2).

Figure 3. Test of simple effects of significant interaction terms from two-way ANOVA by pairwise comparison of least square means. Panel (a) is least square mean P50 ( $\pm S E)$ across forest ages for each species.

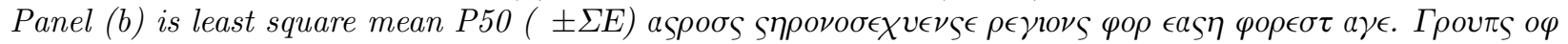

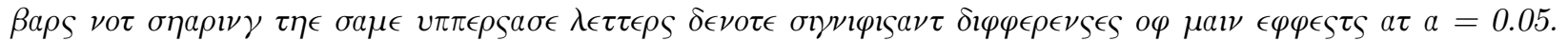

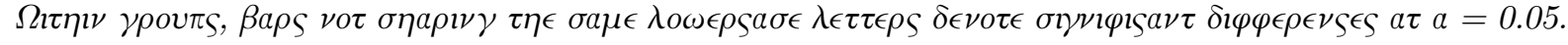

Figure 4. Mean xylem lumen area ( $\pm S E)$ across chronosequences (Panel (a)) and age (Panel (c)). Groups of bars not sharing the same uppercase letters denote significant differences (p [?] 0.05) between species, while bars within groups not sharing letters denote differences within species among ages or chronosequences from a two-way ANOVA with species and age as fixed factors. Panels (b) and (d) show the relationship between 
mean lumen area and mean specific embolism threshold of individual trees assessed by linear regression. Lines are best fit from linear regression when slope is significant $(p<0.05)$.

Figure 5. Mean vessel density ( $\pm S E$ ) across chronosequences (Panel (a)) and age (Panel (c)). Groups of bars not sharing the same uppercase letters denote significant differences $(p<0.05)$ between species, while bars within groups not sharing letters denote differences within species among ages or chronosequences from a two-way ANOVA with species and age as fixed factors and region as a blocking factor (Table 2). Panel (b) and (d) show the relationship between mean lumen area and mean specific embolism threshold of individual trees assessed by linear regression. Lines are best fit from linear regression when slope is significant $(p<$ 0.05). Solid lines are best fit across species and dashed line is at the species-level.

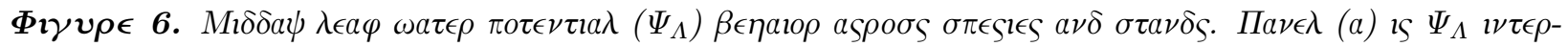

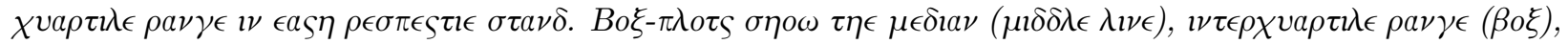

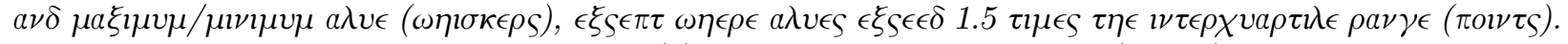

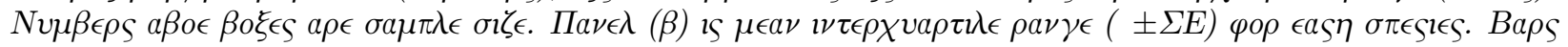

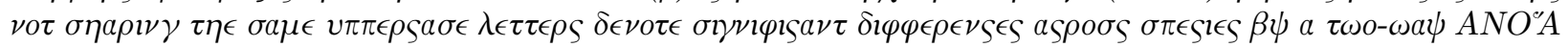

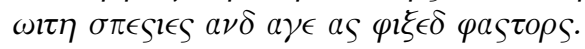

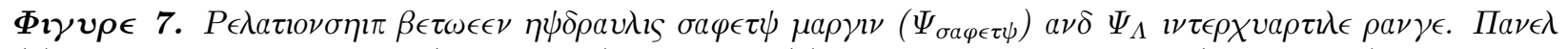

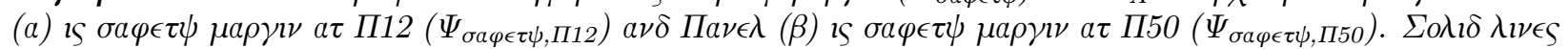

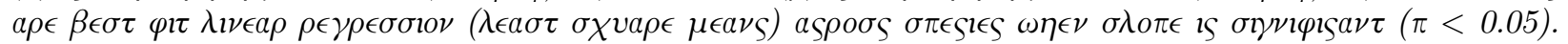

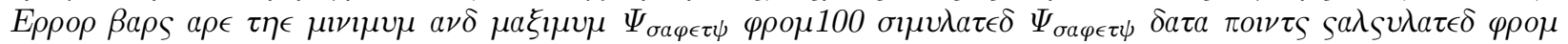

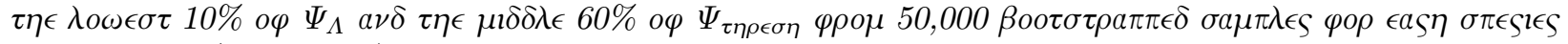

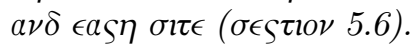

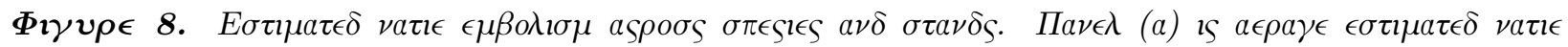

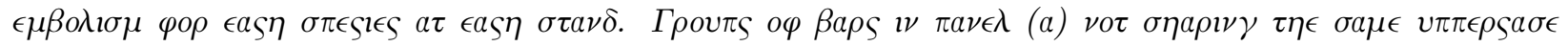

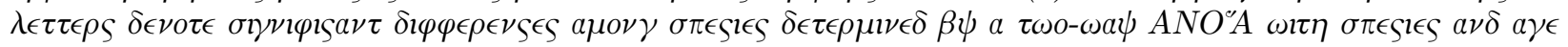

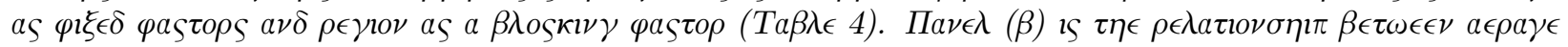

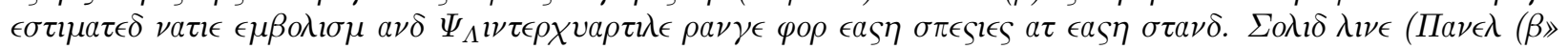

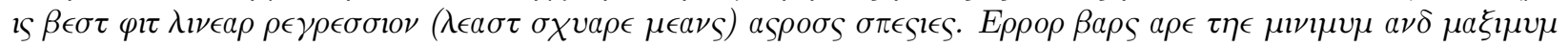

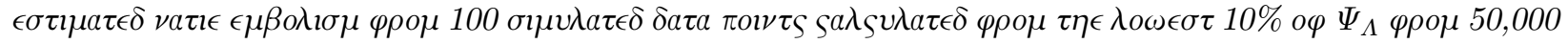

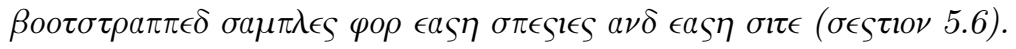

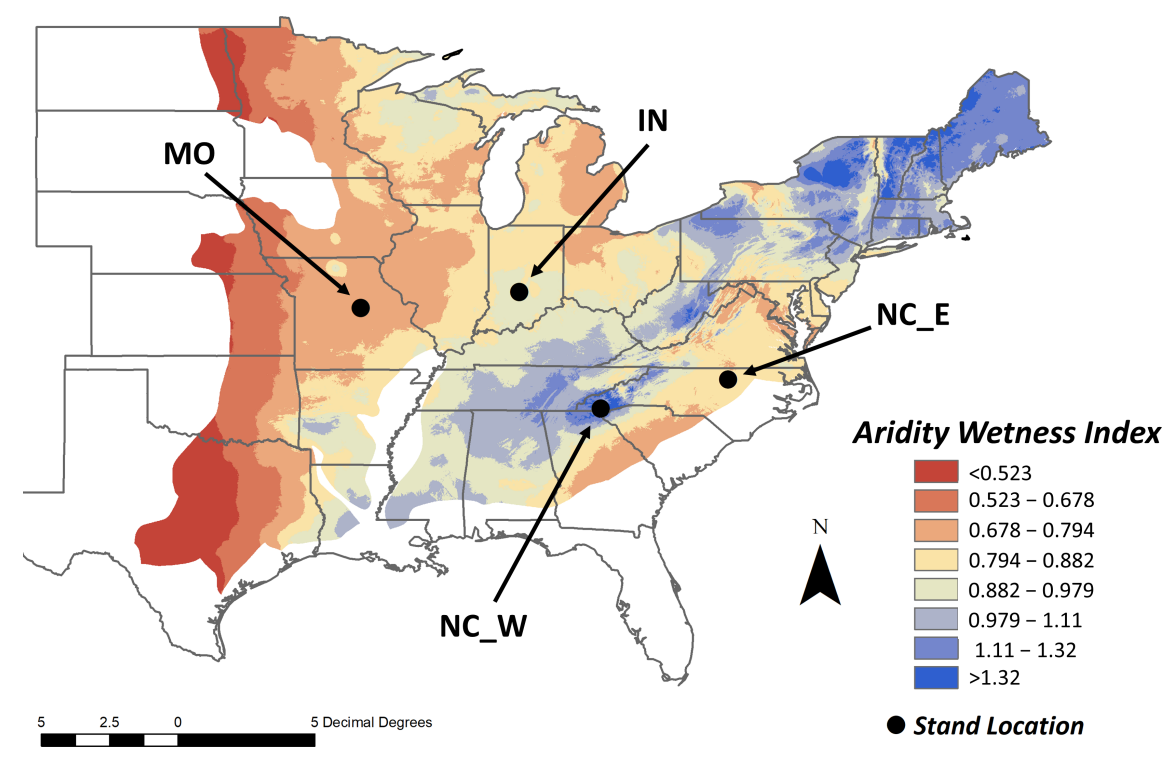



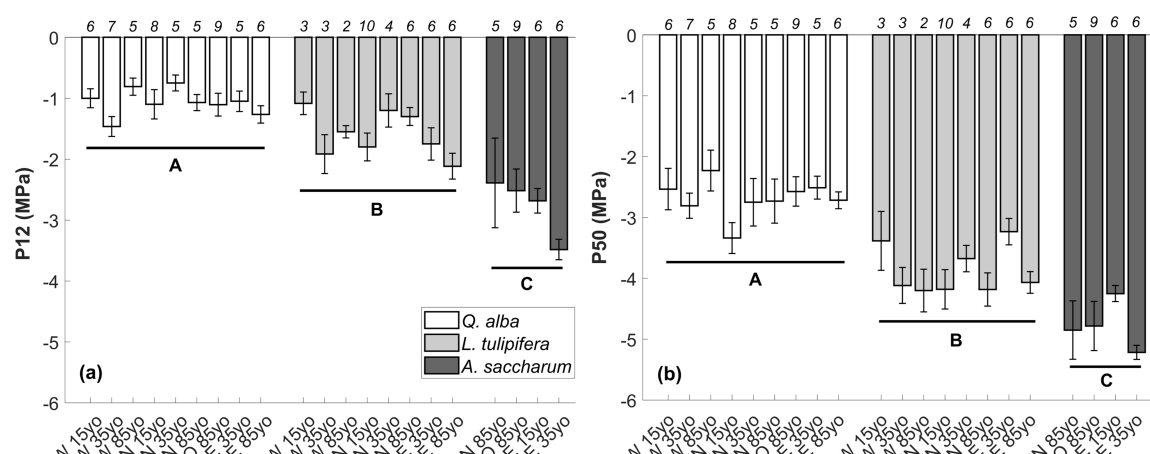
153

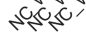

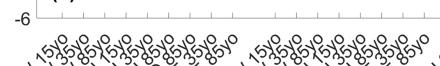

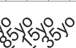
7. asos.

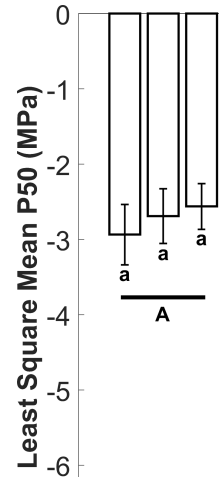

(a)
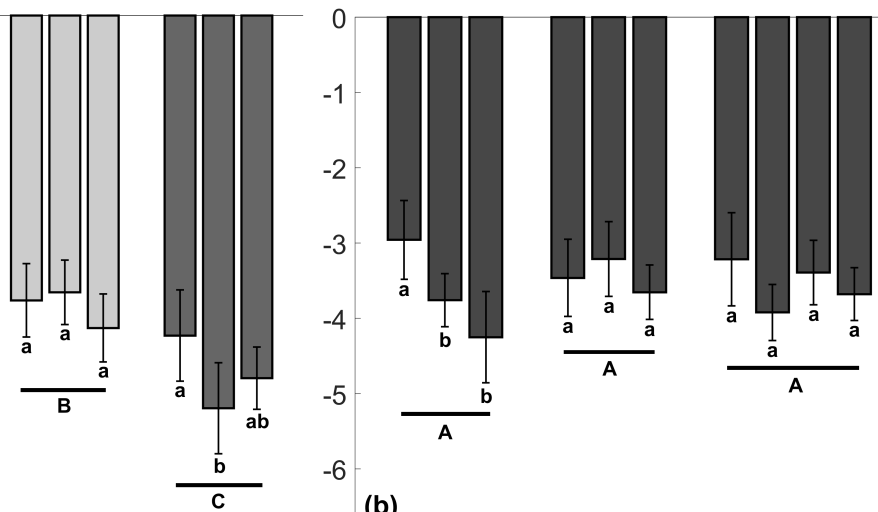

(b)

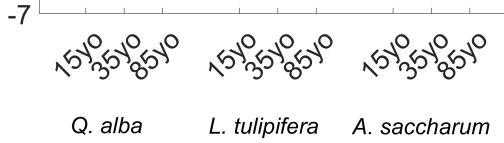

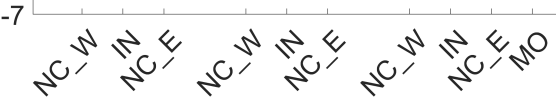

$$
\begin{aligned}
& 15 \text { yo } 35 \text { yo } \quad 85 y o
\end{aligned}
$$
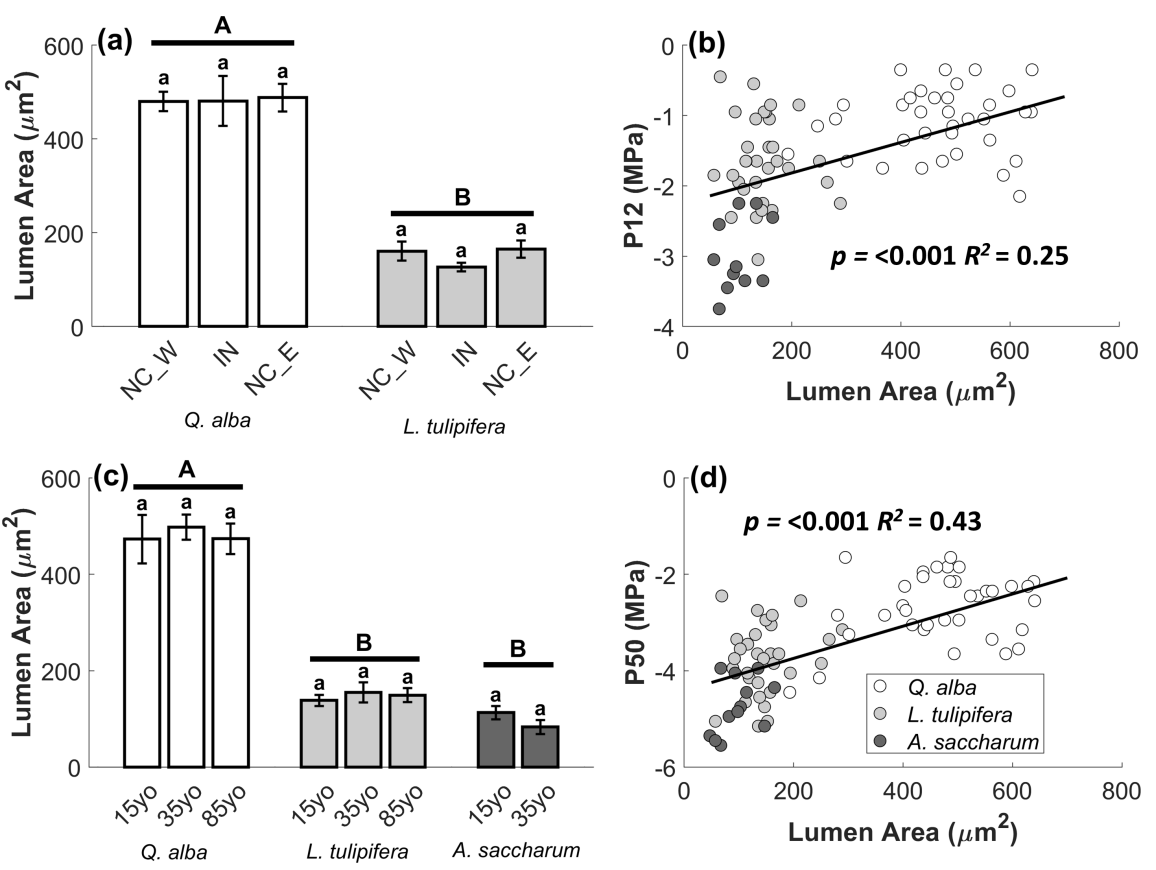
(a)

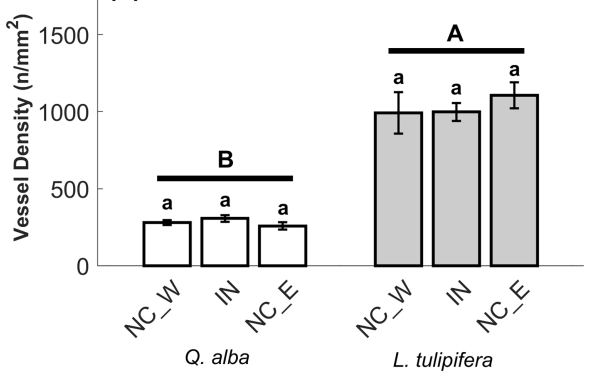

(c)
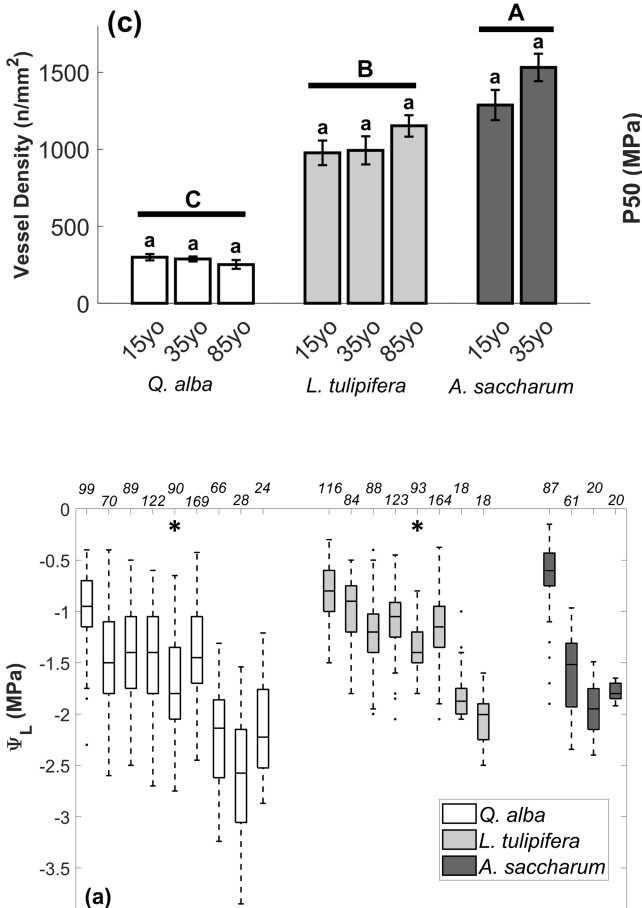

(a)

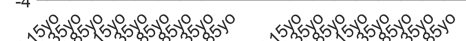

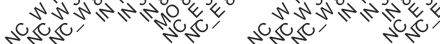

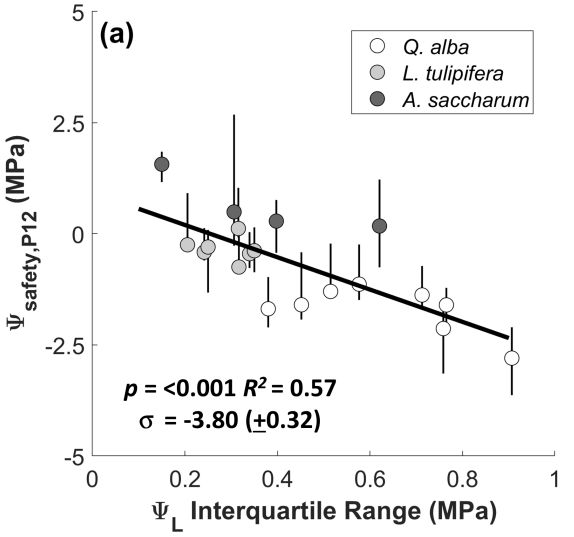

(b) $p=0.002 R^{2}=0.26$
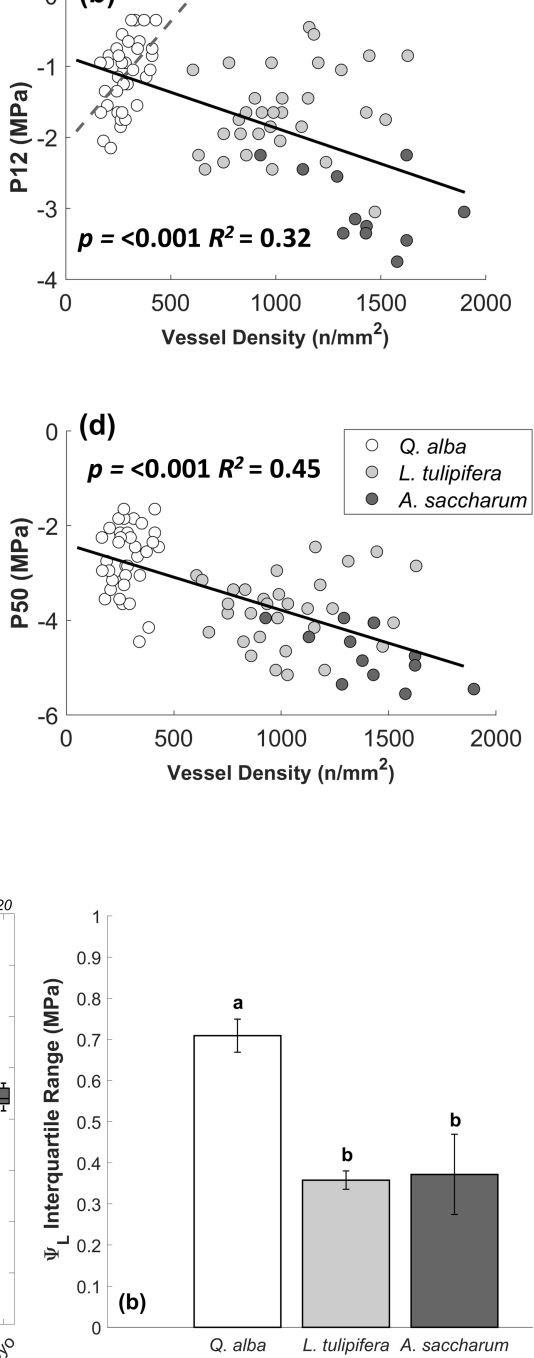

${ }^{5}$ (b)

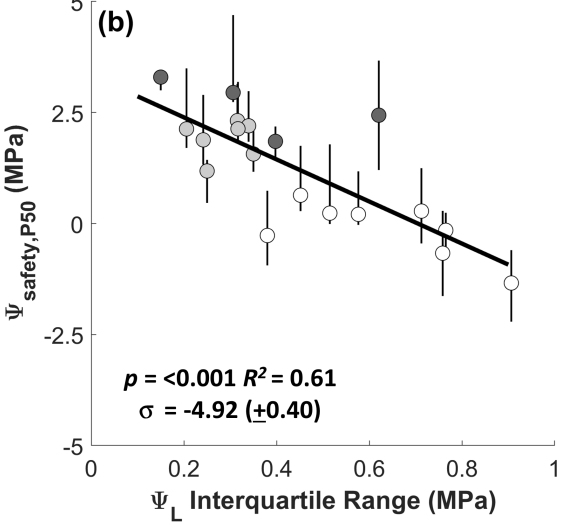



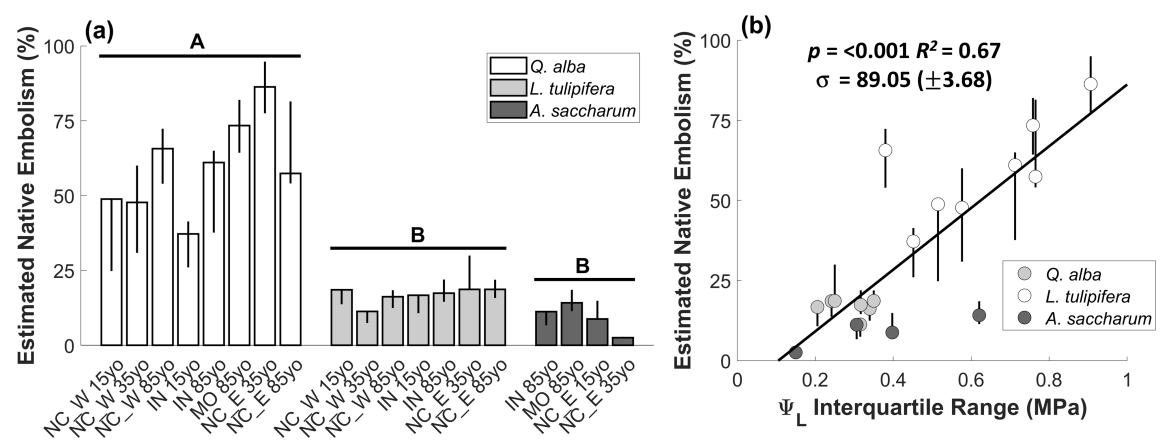